\title{
The Need for an Informational Systems Approach to Security
}

\author{
José María Díaz Nafría
}

Department of Psychology, Sociology and Philosophy; Universidad de León, 24071 León, Spain. E-mail: jdian@unileon.es

\begin{abstract}
Different senses of security and its related assumptions, methodologies and contexts are analyzed by first reviewing the liberalistic notions of security and trust, unveiling, on the one hand, the contradictions exhibited between discourse and practice; on the other hand, the historical strategy of concentration of power behind the liberalistic doctrines. The weaknesses, limits and implications of the liberalistic notions and methods on security and trust are inquired, and subsequently a genuine horizon of security as sustainable and general procurement of positive freedom is advocated.

The CyberSyn project successfully implemented in Chile, but tragically and prematurely ending under the hard power in the 9/11 of 1973, serves as model of the posed system approach to security. However, the system model is actualized and completed with elements of the general theory of information in virtue of: the increased complexity of societal systems, its ultimate global dimension, its biospherical closure, the increase of information assets and processes, and some epistemological boundaries. These reasons also set the need of keeping -beside the system approach- a critical and ethical stance.
\end{abstract}

Keywords: security, trust, systems theory, information theory, General Theory of Information, political economy, political philosophy, liberalism, political history, surveillance, control theory, critical theory, information society

Acknowledgement: The author wishes to express his profound gratitude to Peter Fleissner, Rafael Capurro and Mercedes Osorio for their kind and careful reviewing of the manuscript, their valuable comments, suggested improvements, and the stimulating discussion on ethical, political and economic topics.

Before undertaking our inquiry into security, let us recall the famous fear arisen in the XVIII century concerning the stability of the solar system. Regarding some of Newton's ideas on the dynamics of planetary bodies including his belief on a periodic divine intervention (Newton 1729), and the surprising success of his mechanics in the prediction of so many terrestrial and celestial phenomena, the fear about the possible collapse of the solar system started to propagate, nourishing the secular apocalyptic picture. With the perspective of the possibility of non preservation of the earth, it was hard to feel secure in everyday life, so the question about the stability of the Solar System became a scientific problem of societal relevance. Fortunately, this question was tackled by one of the most outstanding thinkers of the time, Laplace, who succeeded in proving the so desired stability of the system in spite of the multiple body interaction problem, which could not be handled by Newton's method (Laplace 1990, Whitrow 2001). Solving this problem, Laplace developed an excellent mathematical tool, used till our days in the analysis of the stability of a system. Later on Poincaré (1905-1910) probed the inaccuracy of Laplace's approach, but the approximation was, in any case, reasonable enough to bring quietness into everyday life (Poincaré 2003).

Within the given example, we might distinguish between objective and subjective uses of security. On one side, the solar system was probed to be secure because its continuity was certain; on the other, XVIII century peasants felt secure because the danger of non preservation of their world -therefore their lives - did not exist. System preservation is something objective - if we are able to grant an outer observation -, but the feeling about the confidence or certainty in the stability 
of environmental conditions is subjective. Concerning this second acceptance, Maslow (1943) considered in his well-known hierarchy of needs security as the second level, right above the most elementary physiological needs as breathing, eating, etc. Thus, both continuity (preservation) and certainty (foresight) are the main notes of the common uses of security.

Being these notes so fundamental to any life, it is clear that no fear can arise against knowing about the security of the solar system. However, there are good reasons for some subjects to suspect against some security measures when they correspond to the certainty about the continuity of the problems, which are hindering the own subject's security. This can happen because the stable state entails some unfairness or because we are talking about some heteronomous security.

In our inquiry into security we will deal with these questions, adopting a critical stance towards the uses of security and trust in liberalism, and adopting an information-systems approach aware of the hyper-complexity of social systems, as well as some fundamental epistemic boundaries.

\section{Security and Trust in Historical Perspective: Between Liberalistic Groundings and Discourses}

In the last decade, an increasing stress on security concerns has spread at different levels of social life. But contradictorily, it has been coincident with a major recession of social security systems, and the consolidation of the Information Society, idealized as a transparent and borderless global community. Despite the policy and discourse changes after September $11^{\text {th }}$, these contradictory moments could also be ascribed to the inherent contradiction of the liberalistic discourse versus its interventionism and protectionism at critical stages. Perhaps to veil this contradiction or just to make it more pleasant to the audiences, the liberal discourse seems to prefer "trust" at the stakeholder level, while "security" is rather used at the policymakers level. We might indeed see trust and security as two faces of a same coin, which is reversed depending on the audience and depending on the severity of the concerned problems. Furthermore, we can ask whether this current emphasis on security - stressed from September $11^{\text {th }}$ and relatively absent in the previous decade (Mattelart 2003, chapter 6) - cannot be considered as a phase of a pendulum present in the history of liberalism along the centuries, in which the role of public institutions as guaranties of security order is differently weighted depending on the feeling of dangers (Rivero 1998).

\subsection{Historical Notes on the Liberalistic Use of Security and Trust}

A key to understand the forces moving this pendulum is provided by the $19^{\text {th }}$-century German economist Friedrich List:

"It is a very common clever device that when anyone has attained the summit of greatness, he kicks away the ladder by which he has climbed up, to deprive others of the means of climbing up after him [...]

Any nation which by means of protective duties and restrictions on navigation has raised her manufacturing power and her navigation to such a degree of development that no other nation can sustain free competition with her, can do nothing wiser than to throw away these ladders of her greatness, to preach to other nations the benefits of free trade" (List, 1885, pp. 295296)

\subsubsection{Liberalistic Pureness and Digressions}

As illustration of this kicking away the ladder, the political economist Ha-Joon Chang (2003) reminds the period of British protectionism and aggressive trade policy between the 1721 reform of 
Robert Walpole - Britain's first prime minister - and the repeal of the Corn Law in $1846 .{ }^{1}$ This abolition (often interpreted as the definitive victory of liberal economic doctrine) caused the "great famine" that struck Ireland from 1846 to 1849 maintained by the "political courage" ${ }^{2}$ of the liberalistic doctrinaires, which imposed the principle of no intervention and brought about the death of 1,5 million people (Warde 2007). However, this non-interventionist courage was circumvented during this liberalist phase, for instance, in the case of the opium wars in which - by means of the "unequal treaties" of Nanking (1842) and Tianjin (1858) - the weak Qing's China made significant trade and territorial concessions, including the mandatory legalization of the opium trade which led to addiction to millions of Chinese people (Stiglitz 2002, Golub 2006, Roux 2004). These measures had also the consequence of deindustrializing China, sinking its manufactures (particularly the iron and steel industry) until the XX century, though they were globally dominant until the XIX century.

Moreover, if we regard the mixtures of reasons and lies to justify the intervention starting the Second Opium War, and the afterwards looting of the Summer Palace by the Anglo-French troops, we can find despite obvious differences also relevant similarities with the 2003 Iraq war: (1) false arguments were used aiming at legally disguising the intervention, which were publicly falsified (Cobden 1857); (2) it came to complete the previous opium/lraq war, making stable the related concessions; (3) it brought about a colonialism de facto though with a restricted political and social control - except to foreign trade concerns; (4) it hindered the wealth and development of the country on a long-term basis; (5) the losses of historical and artistic assets had a symbolic value of defeat (Hugo 1985); (6) a number of separatist, ethnic and religious rebellions - favored by the weakened inner government - brought about high human and economical costs (Gernet 1996; Ramonet 2004; Lafourcade 2007).

Nevertheless, whereas the British interventionism did not represent a significant change in its foreign and domestic policy, the second Iraq war exemplified the clear superseding of the soft power paradigm promoted in the 1990s by a hard power imposed since September $11^{\text {th }}$ (Mattelart 2003, chapter 6): if the commotion of the 9/11 facilitated the deployment of the hard power for the benefit of the civil society, the Iraq war represented the turning away from that civil society that globally opposed the war (PewGlobal 2003). But besides the relative decline of this hard power after the mired military supremacy in Iraq and Afghanistan and the 2008 stock market crash imposing a moderation, at least at the discourse, in the military projects -, what is the essential difference between these hard and soft power? Does the latter comply with liberalism, while the former enters in contradiction with this doctrine?

\subsubsection{Soft vs. Hard Power: Between Lyric and Obsession}

Every one in the world knows that the soft overcomes the hard, and the weak the strong, but no one is able to carry it out in practice. (Lao-Tse, 1995, §78.1)

It is true that, on the one hand, the soft power - coined and advocated by Joseph Nye (2004) was aligned with the "Global Information Dominance" as a goal pursued by several non-coercive actions of the United States to procure an advantageous position in the realm of free, commercialand strategic- information ${ }^{3}$; while, on the other hand, the hard power has been aligned with the attempt of a domination based upon a blend of force, economic and financial mechanisms focused on enemies, production and consumption (Mattelart 2003). In consequence, the soft power harmonizes - in the sense of not involving coercion and the appearance of enabling free-willing with the projects of the global information society and its related democratic ideals of an un-

\footnotetext{
${ }^{1}$ In the case of the United States, it is not until the time after the Second Word War when it converts to the free trade though not as much as Great Britain in the middle of the XIX Century (Chang 2003).

2 including Prime Minister Robert Peel's “moral greatness" highlighted by Queen Victoria (cited by Warde 2007, p. 19).

${ }^{3}$ Among these actions, it is worth mentioning: the usage of the Echelon network for economical espionage; the creation of the National Imagery and Mapping Agency in 1996; the Future Imagery Architecture initiative initiated driven by the National Reconnaissance Office also initiated in 1996, the liberalization of the Global Positioning System in 2000 to prevent competition from the Galileo system (Virilio 1999, Matterlart 2003).
} 
mediated, borderless and self-regulated world, whereas the hard power better harmonizes with the disciplinary and panopticon archetype. ${ }^{4}$

But it is no less true that the purpose of getting advantage and achieving domination remains in both cases, and that the usage of coercion was compatible in principle and practice with the soft power: In principle, because the preference of co-option to coercion - as it has been stated (Nye 2004) - is utilitarian, and therefore subject to the results; in practice, because during the time in which the soft power is allegedly preferred by US foreign policy, significant military actions also took place: Iraq 1993, Somalia 1993, Haiti 1994-1995, Bosnia 1995, Iraq 1998, Sudan 1998, Afghanistan 1998, Serbia 1999, East Timor 1999-2001, etc. ${ }^{5}$ Furthermore, though there are evident differences in the degree of coercion during the decades of 1990 and 2000, the surveillance initiatives involved in the "Global Information Dominance" in the 1990s were a deployment de facto of the panopticon assisted by the new digital technologies (see note 3; Bentham 1995, pp. 29-95).

In order to understand better the relation between these two kinds of power - apparently antagonist -, it is enlightening the comparison stated by Michel Foucault between Bentham's Panopticon and Rousseau's topics of transparency:

"Bentham was the complement to Rousseau. What in fact was the Rousseauist dream that motivated many of the revolutionaries? It was the dream of a transparent society, visible and legible in each of its parts, the dream of there no longer existing any zones of darkness [...] It was the dream that each individual, whatever portion he occupied, might be able to see the whole society " (Foucault 1980: 152).

Following this comparison, a familiar resemblance can be found: on the one hand, among the expectancies of those who participated in the astonishing communication endeavors in the time of the French revolution (in the 1780s and early 1790s) and the techno-utopias of Piotr Kropotkin (1842-1921), Marshall MacLuhan (1911-1980), Alvin Toffler (1928-) and Nicholas Negroponte (1943-) - to name but a few - (Vázquez 1997, Mattelart 2003); on the other hand, among all those who - being aware of the "zones of darkness" - considered the necessity of shedding new lights into those zones to ensure the advance of the new order, like Bentham. This was the case - with different tendencies- of Edmund Burke (1729-1797), Benjamin Constant (1767-1830) or François Guizot (1787-1874) (Abellán 1998, Rivero 1998). The complementarity of both poles is rooted in the avoidance of harm - hence security. To this respect, Bentham:

"effects the project of a universal visibility which exists to serve a rigorous, meticulous power. Thus Bentham's obsession, the technical idea of the exercise of an 'all-seeing' power, is grafted on to the great Rousseauist theme which is in some sense the lyrical note of the Revolution... When the Revolution poses the question of a new justice, what does it envisage as its principle? Opinion. The new aspect of the problem of justice, for the Revolution, was not so much to punish wrongdoers as to prevent even the possibility of wrongdoing, by immersing people in a field of total visibility where the opinion, observation and discourse of others would restrain them from harmful acts" (Foucault 1980, p.153)

In Gabriel Tarde (1843-1904) we find a blend of both positions: the clarity is shed to the public (molding its opinion, thus becoming "public opinion"), whereas such clarity cannot get into the crowds, in which the crime can be organized (Tarde 1986). Thus, Tarde's approach provides a

\footnotetext{
${ }^{4}$ It is pertinent to mention here those actions that - though continuing the path of those listed before in note 3-represent a change in the degree of intervention: the electronic surveillance measures to citizens under the US Patriot Act; the creation of the Homeland Security Department in 2002 or the Total Information Awareness project launched in the same year and aimed at collecting about 40 pages of information of every person on the planet (Mattelart 2003, Ramonet 2003).

${ }^{5}$ Considering the military expenses it is worth mentioning that although the summit reached in Reagan's administration was not caught again until the period after 9/11, during the 1990s the budget of defense did not come under the average value of the cold war (Gresh et al 2004: 54-55).
} 
criterion to distinguish where to direct the soft and the hard power; ${ }^{6}$ and also provides guidance for social control:

"All the improvements of social organization... have the consequence of enabling that one meditated, coherent, individual project arrives purer, lesser polluted, deeper, and through the safer and shorter means into the minds of all the associated" (Tarde 1986, p. 149)

According to the $\mathrm{XIX}$ th century utopia of journalism, opinion (for instance, Tarde's opinion) "is fair by nature, it disseminates by itself, and it is a sort of democratic surveillance" (Foucault 1980). The naivety of the soft power can be regarded as linked to this utopia, but the reality and eventual complexity of the "co-option" advocated by Nye (2004) is free of the ideal of justice, it is aware of the costs of dissemination, and it serves to the dominancy. ${ }^{7}$ On the other hand, if we explore the historical use of the soft power by the US policy between the Second World War and the neoliberalist reaction in the 1980s, we find it as a complement of military actions - Korea, Guatemala, Vietnam, Dominican Republic (Chomsky 1994) - and economical measures - Breton Woods Institutions, General Agreement on Tariffs and Trade, Organisation for Economic Co-operation and Development, World Economic Forum (Pironet 2007, Díaz-Salazar 2002).

This historical combination of soft and hard measures actually counteracted the raise of a multipolar world coming out the decolonization of Africa and Asia, which claims organized around the multilateral bodies within the United Nations, the Bandung Conference in 1955, the Tricontinental Conference in 1966, and the Non-Aligned Movement (founded in 1961). This intergovernmental organization condemned the economic measures employed to warranty the economic dominancy, and subsequently promoted in 1974 a New International Economic Order (NIEO) to facilitate global fairness. In the realm of the soft power, the Non-Aligned Movement denounced that under the US advocacy of the "Free Flow of Information" doctrine in several international institutions there was an actual promotion of the US telecommunication and cultural industry by the US administration serving to the prevalence of North American culture and communication. Therefore, in parallel to the NIEO also a New World Information and Communication Order (NWICO) was promoted from 1974.

In 1977, the UNESCO convened the MacBride Commission to state the basis of such claimed order. However, the condemns from these stages concerning the imbalance in the communication and cultural domains were received by the US as a partisan defense to the Third World by UNESCO. The extreme reaction was the withdrawal of the US from the UNESCO in $1984-$ followed by Great Britain and Singapore in the year after - (Miguel de Bustos 1994). Again, it can be easily interpreted - using List's metaphor - as kicking away the ladder by which they have been climbing up: In this same year a strong liberalization of the communication and cultural industry started in the US and disseminated worldwide (Schiller 2003).

\subsubsection{A New Criteria to Distinguish Historical Stances on Security}

By looking back on this historical development of the soft power, we intended to show that only at the discourse level it could be aligned with the ideals of transparency, clearness and fairness of the enlightenment. Therefore a new distinction has to be introduced in order to understand the specificity of the aforementioned sociopolitical positions.

But before posing this new distinction, it is still worth pointing out that the soft power was interpreted by some cyber-utopians as an opportunity for the fulfillment of their ideals, and, furthermore, the soft power was presented as a horizon of superseding the hard one in a global

\footnotetext{
${ }^{6}$ As pointed out by Latour (2005) and Kullenberg and Palmås (2008) Tarde's sociology and particularly his laws of imitation constitute a clear antecedent of the surveillance techniques focused on societies and groups rather than on individuals. These techniques are referred as "panspectric" - centered in patterns and social behaviors - in contrast to the concept of "panopticon". Although this kind of surveillance allegedly represents a means to make it compatible with personal privacy, either alone or specially as a combination of both kinds of surveillance, it could increase the danger of social sorting, whose societal consequences might be dramatic as it has been discussed by David Lyon (2002, Zureik et al. 2010).

${ }^{7}$ according to Herbet Schiller (1991) it indeed represents a semantic twist of the "cultural imperialism".
} 
society - similarly to how publicity would work in Tarde's vision when the crowds and criminal organizations would disappear (Nye 2004, Tarde 1986). As previously pointed out, the utilitarian ground of the soft power implies a complementarity with the hard power based in effectiveness, and the awareness that the clarity cannot reach everywhere. ${ }^{8}$ From this point of view, the complementarity between these kind of powers is similar to the one highlighted by Foucault between Rousseau and Bentham.

Thus Rousseau's side is in a sense aligned with the soft power, publicity, transparency, trust and the "control society" depicted by Gilles Deleuze (1990), whereas Bentham's side is aligned with the hard power, coercion, surveillance, distrust and the "disciplinary society". Both sides are concerned with security with respect to the eventual harms in the development of the liberties. Whether one pole or the other dominates explains the pendular movement referred at the beginning of section 1 .

Regarding the liberalistic groundings, though the former side is preferred at the discourse level it corresponds to its lyric -, the general claim for security is at the very foundations of the liberal state as conceived by its early thinkers. For instance, according to Locke: "the enjoyment of the property [in the state of nature] is very unsafe, very unsecure" (Locke 1690: §123), and to avoid this harm, the political society "was first instituted" to the procurement of "safety and security" (§94). In Bentham, it is security the all-important condition of human happiness, and it has to be warranted by government as its very first goal (Bentham 1891).

Since security is conceived as the basic pre-condition for the liberal state, i.e. it settles the frame in which freedom can develop, when moving within this frame, the liberal discourse disregards "security" and prefers to ask for "trust" and "trustworthiness". The frame poses an inside and an outside. However, when the frame is in question, the security concerns jump to the forefront. ${ }^{9}$

Who is at either side - is the open question of exclusion. What harms are going to be avoided concerns the open questions of subsistence and fairness. The non-definition of what harms should be avoided and who should be included within the frame of trust, i.e. what is the extend of the security attainment, explains the broad spectrum of liberalist positions from Burke or Constant to Bentham or Stuart Mill; from Hayek to Keynes (Mellón 1998): on the one hand, the security of the property of a leading minority; on the other hand, a regard closer to the aforementioned Marlow's vision of security and the achievement of fairness.

This observation brings a new criterion to reconsider the previous bipolar distinction (and complementarity) established between Rousseau and Bentham as aligned with the soft vs. hard power complementarity. Considering Rousseau's concern on security and justice (for instance, "the first rules of justice: for to secure every man his own, every man must have something" (Rousseau 2007: 71)): justice, security and equality belong to a same plane, therefore it is unmerited aligning his position with the soft power, since the basis for the latter is domination. And it is also unmerited aligning Bentham's position with the hard power since the latter disharmonizes with Bentham's well known criteria of "the greatest happiness of the greatest number" as the "measure of the right and wrong" (Bentham 1891, p. 93) and the fundamental duties he ascribes to government - besides security -: subsistence, increase of wealth, and equality (Abellan 1998, p. 23).

If the distinction between the soft and the hard power reflects a shift concerning authoritarianism - from free-willing to coercion -, equality serves now as criteria to distinguish between the position of either the soft or hard power with respect to those held by either Rousseau or Bentham -from inequality to fairness. Fig. 1 schematically deploys these distinctions.

\footnotetext{
${ }^{8}$ To this respect it is remarkable that a claim to rebuild a US soft power in 2008 was based upon the evidence of the worldwide adverse opinion dramatically growing during the years of hard power prevalence (PewGlobal 2008). Moreover, though during the years in which the soft power has been partially restored, the US expenses devoted to the hard power have not turned back (Johnson 2010).

${ }^{9}$ The relation among trust, security and the frame erected by government is exposed by Locke: "those, who like one another so well as to join into society, cannot but be supposed to have some acquaintance and friendship together, and some trust one in another; they could not but have greater apprehensions of others, than of one another: and therefore their first care and thought cannot but be supposed to be, how to secure themselves against foreign force. It was natural for them to put themselves under a frame of government which might best serve to that end..." (Locke 1690, §107).
} 
Most utopias - and particularly the techno-utopias a la Kropotkin (MacLuhan, Etzioni, Toffler, Barlow, etc (Mattelart 2003)) - are located at the periphery of Rousseau's quadrant of fig.1, whereas the dystopias like those proposed by Orwell (1949), Huxley (1932) or Bradbury (1953) locate at the periphery of the other quadrants. Considering the aforementioned liberalist positions, we move downwards when passing from Bentham, Mill or Keynes' to those of the so-called conservative liberalism.

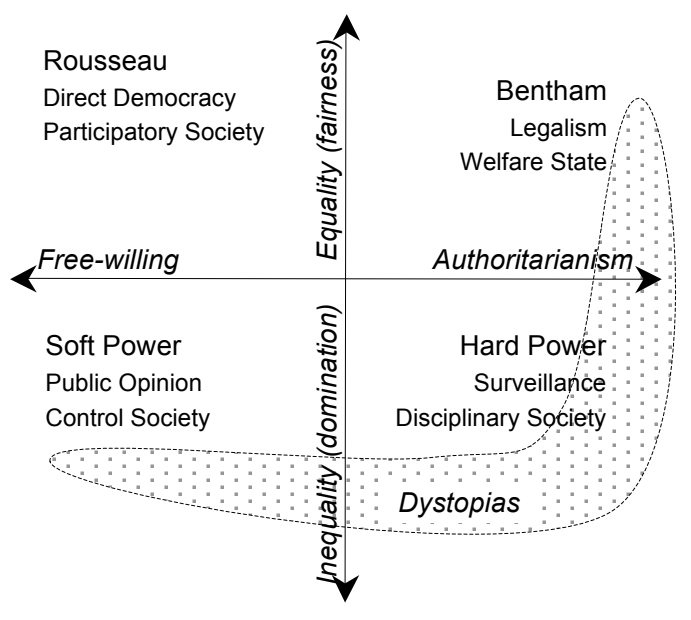

Figure 1: Representation of the political positions discussed in the liberalistic visions of security

The equality issues - as touched by Rousseau's former quotation - give rise to pure economic questions, specifically those related to redistribution, in which dominancy mechanism and the aspiration of equality are directly concerned. As Marx posed (for instance, in the Grundrisse, his Critique of Political Economy or the Capital) it is the development of the productive forces within the frame of the existing productive relations - reflected and legitimized in the property relations - that leads to the contradictions between the productive-forces and relations (Marx 1859). This process - especially under the capitalist economy in which the productive forces are impelled towards a "free, unobstructed, progressive and universal development" (Marx 1973, p. 540) - brings about a repetitive obsolescence of the productive relations and the subsequent necessity to re-express the productive relations in the existing political frame (Elster 1983, pp. 209-236).

This inherent contradiction is particularly reflected in the capitalist democracies where the productive forces evolve within capitalist economy, while the productive relations and the corresponding property legitimacy evolve in the liberal democracy. As argued by Bowles (2007), this opposition of forces (corresponding to a logical contradiction between pure democracy and capitalism, namely equality vs. inequality, or participation vs. dominancy) requires a recurrent agreement obtained under pressure which terms are updated in a constant struggle.

\subsubsection{Globalization and Information Society}

Until the decade of 1970 s the equilibrium between democracy and dominancy was chiefly actualized in the liberal democracies, where the general rights upon factual participation and production were respectively waived by means of the extension of salary and suffrage (Bowles 2007). However, especially after the 1990s the relative equilibrium of the decades before 1980 was undermined at the democracy pole due to several factors:

- The deflation of the labour productive force because of the introduction of automatic technologies - as Wiener, among many others, tried to prevent (Noble 1993, Al Hadithi \& Díaz 2010a)-; 
- The introduction of the Information Technologies linked to completely new productive relations, which can easily evolve at the global scale with independence of the national boundaries though they still need the States in order to legitimate and secure the corresponding productive relations. $^{10}$

- Advocacy of capitalist interests by unobstructed international institutions after the dissolution of the opposition led by the Soviet Union - e.g. OECD, International Monetary Fund, World Bank, World Trade Organization (Stiglitz 2002);

- The global liberalization of labour as a part of the liberalization of the world economy significantly assisted by: the information technologies, the automation of the productive processes and the growing power of transnational corporations.

Whereas in the previous situation the re-expression of the productive relations was chiefly negotiated within the liberal democracies, at the current stage of development of the productive forces, the Global Institutions represent a new means -besides the productive forces itself- to press the terms of the agreement with the national states, which still legitimate the productive relations.

It is here worth pointing out that the previously referred protection of the Information and Communication Technologies between World War II and the 1980s erected a significant oligopoly concentrating not only economic power but also political power, since the related media industry has the possibility to drive significantly the public opinion - as it was condemned by the NonAligned Movement. This fact offers a different conception of the ladder that was thrown away in the liberalization of the Information and Communication Technologies to which we previously referred: it was not only a national state which climbed up through the ladder; instead an international stage was erected driven by transnational corporations through which the role of the national states and the liberal democracies could be undermined. ${ }^{11}$

Thus, the pressure, previously exerted by productive forces within the frame of the national states in order to actualize the productive relations, found a second mechanism to improve its efficiency at the pole of the capitalist interests: the pressure could now be driven through international institutions forcing the actualization of the national legislations, using mechanism as, for example: the structural adjustments of the international financial institutions, the Agreements within the World Trade Organization, the restrictions imposed to the States via regional institutions as the European Central Bank, the North American Free Trade Agreement, etc.

Within this context, the recent affair of WikiLeaks is interesting in order to reveal the security concerns with respect to digital technologies and social networks. The open debate has centered in the security challenges opened by digital social media, and even some measures have been taken to avoid eventual harms - though no relevant security incident derived from the published information is known. As Christensen (2010) argues, this debate usually presupposes what he considers as 3 myths - that can be ascribed to the aforementioned current of the techno-utopians: 1) social media represents an emerging power; 2 ) the national state is undermined by the forces of the digital age; 3 ) the obsolescence of the public opinion traditional mechanism. However, as the author shows, it was not the publication by just social media, but thought conventional media (particularly The Guardian, The New York Times, Der Spiegel) what gave rise to the actual impacts

\footnotetext{
${ }^{10}$ As argued by Peter Fleissner (2009), the commodification of goods previously belonging to the sphere of culture by means of the Information Technologies requires updating the concepts of the Marxist economic theory allowing us to grasp such process and how the productive relations actualize. A proper understanding would even open the possibility to decommodify those goods that left on the hands of markets could have dramatic consequences. At this eventual decommodification path, Dan Schiller (2009) stresses the double face of the new modes of dominancy created by the digital capitalism: bringing about inequality but also new possibilities of reconstruction and resistance.

${ }^{11}$ To this respect, Herbert Schiller argued that the changes in the international geopolitical arena - occurred at the end of the 1980s and the beginning of the 1990s, "though still bearing a marked American imprint, is better understood as transnational corporate cultural domination" (Schiller 1991: 19). And this is still the case as we can see, for instance, in the list of the ICT industrial giants, though the number of corporations has reduced, while corporations from China, India, and other Asiatic, American and African countries start to be included in the list with growing weight (Dan Shiller 2009).
} 
of the published information - thus (1) and (3) are ill-founded. On the other hand, it was not a rootless social media that allegedly threatened the National Security, on the contrary it was the Swedish, Belgian and Icelandic legislation, which support the legitimacy of WikiLeaks - thus also (2) was ill-founded.

What this case actually shows is on the one hand, the effective power of the conventional public opinion; on the other hand, the importance of the National States as the Institutions in which the social and productive relations legitimize, and furthermore, a small but possible subverting of the control effected by the dominant stakeholders. If it were a risk for the dominancy relations, it might represent a security issue of the liberal state - according to its groundings.

\subsection{Methodological Approaches and the Liberalistic Model of Trust}

The shift between the security and the trustworthiness, mentioned at the beginning of section 1 , also reflects a methodological change between a systems- and an individualistic approach respectively, being the latter more consistent with liberalistic doctrines, and therefore exhibiting a higher coherency at the liberal discourse level. On the other hand, the systems approach on security is given by the fact that security is considered at the level of the social-, political-, economical- or technological systems (particularly, information and communication systems when referring to security in the information society).

The dominant account of trustworthiness -as it can be found for instance in the RISEPTIS report (2009), aimed at steering the European administrative and industrial policy in trust and security concerns, is usually reduced to an individualistic model in which only three parts enter the scene: $A$ trust in $B$ to do $X$. It is easy to find here a commercial continuity: if $A$ trusts in $B$, then $A$ will pay to $B$ the costs of doing $X$. The awareness model is based on the reliability of doing $X$. Having $100 \%$ effectiveness is not needed, since trust tends to be bipolar; just a relative high reliability is required. Therefore, the achievement of trustworthiness can stress in the good achievements of doing $X$ and forgetting about the rest. The road is open to a fully commodification of doing $X$, and even of achieving trustworthiness, which might be envisaged as a supplement given to $X$; namely, some kind of brand needed to success in the market.

This is not the only way to consider trust, but how it is nowadays predominantly addressed (Luhman 1979, McKnight and Chervany 1996, RISEPTIS 2009). In any case, one of the basic aspects of trust, as stated by Luhmann, regards the reduction of complexity, namely if we trust on another agent we can forget all what is involved in "doing X". Pitifully among all what is being forgotten in this account of trustworthiness, we can find today: the many divides within our societies, between countries, cultures, genders (Ruedin and Hanimann 2007, Capurro and Díaz 2010); electronic-waste, and non-regenerability of resources (Feilhauer and Zehle 2009), etc.

Especially depending on the position taken in the plane represented in fig. 1, the account of security (and trust as its counterpart) concerns a different realm of what harms are being excluded. Subsequently, the included trustful relations are correspondingly different. For instance, if fairness is pursued, then social relations, which cannot be reduced to the previous model of individualistic interplay, come to the forefront.

However, if we delve into the social issues appraised in the effort towards a trustful information society, we mostly find awareness just on the information divide ${ }^{12}$. But the concern on this cleft is restricted to two main aspects: (1) how to connect everyone - accessibility -, and (2) how to enlighten people about information means - literacy - (Mastromatteo 2010); while the questions of: (1') whether information and communication systems are really accounting for social needs, and $(2$ ') to what extend they are doing it, are not seriously tackled. These last questions - undoubtedly of higher importance since they are a prerequisite to the former ones - are aligned with the stance

\footnotetext{
${ }^{12}$ This was, for instance, the only specific social issue (i.e. excluding for instance privacy concerns) included in the agenda of the European Conference Trust in the Information Society (TrustIS) organized by the European Commission in León, Spain, February 2010. And curiously, this issue was tacked by a Brazilian contribution (see: TrustlS 2010, Díaz 2010a).
} 
taken in social security systems in which a systems approach is taken, but are relatively alien to an individualistic / liberal approach for which the "invisible hand" solves such kind of questions (Smith 1759).

Beyond what is concerned in the security and trust endeavors, if we analyze who is involved and how these issues are faced, we observe again the absence of the social sphere ${ }^{13}$ and the circumvention of complexity (Díaz 2010a). On the one hand, the endeavor is primarily treated as an industrial and administrative issue with relevant private consequences. On the other hand, two main approaches are pursued: (i) a projective top-down approach - trustworthiness by design and (ii) a bottom-up approach, reduced to the observation of how users trust on service procurement and all its related elements. However, it is the simultaneous combination of the downwards and upwards causation (respectively stressed in each of the above approaches) which characterizes the systems approach, and it is the complexity of social systems and its interplay with information technologies which - to our belief - claims for a systems approach on security and trust, or their counterparts: exclusion, fear, mistrust... namely, the manifestation of social rifts.

Therefore, we will focus the problem considering a systems approach, and analyzing security rather than trust, though bringing social needs to the forefront. From this analysis we will try to understand the roots of the distressing senses of security - as they are felt in the street - and the possibility to build a more constructive sense of security as a fundamental element of a sustainable information society.

\section{Senses of Security}

\subsection{Common Sense of Security}

As we have previously discussed, the sense of security - even at the liberalistic groundings has been significantly different among authors, historical periods, and sociopolitical contexts depending on the interests at stake. As any other word its senses are the result of a combination of forces corresponding to settled uses and living interests. Thus, since the etymological sense provides, at least, a starting point, this sense is somehow present in the current usages, as it is the case of "security". The Latin adjective "securus" (-a, -um) - from which security comes from blends "se" (without, free from) and "cura" (care), i.e. "free from" care (Harper 2001). Therefore, this primitive sense points to the state in which there is no reason to care about, and consequently normal life can go on. ${ }^{14}$

The common use is very close related to this etymological sense, especially in the passive value of being protected against harm, since in case of being in such state we do not have any care about harms. However, the term also adopted the active value of those measures providing the state of security (as it is particularly reflected in the verb "secure").

Since special care is taken when the threaten value is cherished, security focuses on those values, and particularly if the survival of an object, relationship or subject were threaten. It is nonetheless important to stress the difference to plain survival, since it represents just a minimum in the security procurement, corresponding to the necessary conditions to exist; whereas normal life - in which we can "feel free of care", safe - usually develops in a social frame of broader possibilities, in which different goals can be pursued. Therefore, security "involves the general ability to pursue cherished political and social ambitions" (Williams 2008, p. 6).

\footnotetext{
${ }^{13}$ Though RISEPTIS recommendation 2 scarcely mentions "social-economic actors" (RISEPTIS 2009, p.7).

${ }^{14}$ Especially the passive use of security is very close to the primitive sense of "safety", which came to English through the French term sauf, derived from the Latin salvus, free from being injured (Harper 2001). Although often both senses are used as synonym, in same contexts these words have specialize referring safety to the condition of being protected against natural or accidental harms, whereas security refers to intentional harms. The corresponding measures being taken can be regarded as passive, for safety, and active, for security, since the latter are interested in the causes and the former in effects.
} 


\subsection{Different Senses of Security}

Analyzing the elements of the given broad and common concept of security we can delve into the different understandings of security. Analyzing the previous definitions we can easily distinguish the following values of security:

- Subjective: which is twofold: (i) who cares or not about something; or who estimates something as valuable enough to take special measures for its preservation (the subject can be individual or collective); (ii) the appreciation that the estimated values or objects of security are threatened or not. The first concerns individual or collective values and objectives, the second is fundamentally cognitive.

- Objective: which is also and correspondingly twofold: (i) what is being estimated/protected; (ii) the fact that the survival of whatever is estimated is stable or not. The first concerns something that is, the second its future being.

- Relative: which is a direct consequence of having subjective and objective values, and therefore the corresponding relationship is also double faced: (i) referred to the estimation; (ii) referred to the perception of its stability.

- Passive: being protected against harm.

- Active: measures taken to ensure the preservation of whatever is estimated.

- Gradual: the alleviation of threats can have different degrees, from complete avoidance of harm to a moderate alleviation. In any case, security (as we mentioned in the case of trust) tends to be bipolar: somebody cares or not about a threat. Because of practical reasons, this allows designing and achieving security even when the objective avoidance of harm is not absolute.

By changing the different subjects, objects and the prevalence of either passive or active values and also its degree, we can obtain a complete catalogue of the different uses of security (for instance, an individual regarding its properties; a state regarding political stability or military threats; a community regarding its subsistence; the global society regarding the preservation of the biosphere; sane or obsessive security, etc). However, it is worth - for the sake of simplicity distinguishing major trends and contexts.

To this end, it is useful recalling the plane used to differentiate the political positions in the liberalistic practice and discourse (fig. 1). It is clear that if we move in the direction of increasing equality the subject of security (in the first sense) changes from a dominant group to the involved community, and correspondingly also the objects will change, for instance, from property to subsistence and general well-being. Also in the case of a horizontal displacement from authoritarianism to free-willing, the subjects of security (now in the second sense) change: from a specialized minority - social subsystem - who evaluates the threats and decides measures to the involved community who assets and decides; and the objects will also change correspondingly, for instance, from means enabling social control and governance to means for driving public opinion or the attainment of effective freedom and participation.

We can even attain a simpler distinction if we focus on a general displacement towards the ideal of a fair and participatory society from any other position of the plane represented in fig.1. It is possible to distinguish two major trends of security in case of distancing or approaching to this goal security as attainment of power, or general and effective freedom, respectively. ${ }^{15}$

To this antagonist partition corresponds also an antagonist division of procedures: concentration or distribution of security means. In the case of power procurement, the process of estrangement/alienation of the subject with respect to the object being protected opens the process of commodification of such objects, which is also extended to the means being taken to protect the

\footnotetext{
${ }^{15}$ Similarly, Paul Williams (2008) distinguishes two main security philosophies depending on whether they are based upon either accumulation of power, or emancipation. For many authors, emancipation represents the real path for security. For instance, for Ken Booth (1991, p. 319) "security and emancipation are two sides of the same coin. Emancipation, not power or order, produces true security." (see also Jones 1999, Bilgin 2008).
} 
assets (i.e. the assets and its corresponding security can enter into the market). However, in the case of achievement of freedom, namely emancipation, it is the relation among actors that plays the major role in the achieving of security and it is also mainly relational assets that are being cherished. Though goods are needed for the attainment of factual freedom, it is the cooperative and redistributive links what is important to maintain, and these are ultimately not commodifiable.

In this emancipative type of security, it is relevant to make another significant distinction referred to the character of the intended freedom, which can be either negative or positive. Negative, if it concerns the absence of a threat hindering the enjoyment of freedom, for instance, "the threat of (involuntary) pain, fear, hunger, and poverty" which is, of course, "an essential element in the struggle for emancipation" (Jones 1999, p. 126), but it is not enough to enable the space of open possibilities which characterize positive freedom. It is the achievement of this space of possibilities and the ability to select them what provides a real emancipation, namely a factual provision of freedom.

\subsection{The Contexts of "Security"}

According to the previous analysis of the general concept of security, the subject (in the senses of: who estimates, who assets and who adopts special measures) constitutes the very context where the other elements of security take place. ${ }^{16}$ From this point of view we can delve into the complexity of security distinguishing 5 major contexts that correspond to different security agents:

(s) states, in which both (s1) national security and (s2) social security systems are organized for the attainment of security in neatly different senses: ${ }^{17}$

(i) individuals, in which security can be understood as either (i1) protection of properties and privacy - which corresponds to a negative freedom as argued before - or (i2) provision of basic needs or positive freedoms. They are often envisaged as rights - the former corresponds to a classical liberalistic right; the latter enter into the frame of human rights.

(o) organizations characterized by the pursuit of certain goals and hierarchical organizations driven to its fulfillment (e.g. industrial or commercial companies, non-governmental organizations, research institutions, etc). Similarly, here security can be regarded as the (01) protection of the conditions enabling the pursuit of private goals - as it is supposed in the classical liberalistic groundings, in which those conditions are mainly regarded as properties; or (o2) provision of the needs enabling the pursuit of goals of general interest. ${ }^{18}$

(c) complex societal systems characterized by the pursuit of a multiplicity of goals and heterarchical organizations (as it is the case of our complex societies constituted by several cultural-, religious-, national-, state-, regional-, international-... systems; or in a smaller scale our current universities integrated by groups, departments, institutes, faculties, libraries, etc). Again, it is here possible to distinguish security as the procurement of the conditions enabling (c1) the pursuit of goals exclusively belonging to specific subsystems, or (c2) the pursuit of goals shared or fitted to the global functioning of the complex system.

\footnotetext{
${ }^{16}$ Although the 5 major sectors highlighted by Barry Buzan (1983): military, political, economic, societal and environmental, are seen from an optic in which states seem to be the predominant subjects of security, it is possible to find significant differences among the real subjects of security if we delve into each of these sectors. Even if the corresponding holders were the same, the political or the societal subjects are not equal, since the roles and involved relations are different. In the case of the environmental sector, the subject is broadened in a temporal dimension, since biosphere maintenance corresponds to the interest of future generations.

${ }^{17}$ In this context it is worth distinguishing the different weight of (s1) or (s2) in the US and Europe respectively. Whereas (s1) has been dominant in the US - specially after 9/11 -, (s2) has been preferred in Europe until the terrorist attacks of Madrid, 2004, and London, 2005, and afterwards changed into the preference of (s1) (s. Mattelart 2003).

${ }^{18}$ Though there are certain similarities between (s2) and (01), the former is considered from the point of view of the general attainment of needs of the population, while (01) is regarded as the concrete and technical organization for the achievement of a specific need, for instance, the health or education systems; or even more specific in the purpose and the extent of recipients.
} 
(e) ecosystems, which can be understood as a generalization of the economic realms in which the resources are employed for the fulfillment of the cherished values. Though they are often envisaged in local, regional or planetary horizons, since Vernadsky coined the term of biosphere in 1926, there has been a growing awareness - especially in the last decades - that its ultimate horizon is in any case planetary, since it is the whole biosphere which works as a self-organized system (Tello 1998). Nonetheless, in a broad sense it is again possible to distinguish between: (e1) the security of access to those resources enabling the pursuit of determined goals by the optimization of such resources ${ }^{19} ;(\mathrm{e} 2)$ the administration of resources with respect to general needs as to warranty its future and general fulfillment.

It is easy to see that the line dividing the contexts of type (x1) and ( $x 2)$ - where $x$ stands for any within the set $\{\mathrm{s}, \mathrm{i}, \mathrm{O}, \mathrm{c}, \mathrm{e}\}$ - corresponds to the difference established above between security as attainment of power, or security as attainment of effective freedom (see section 2.2).

But concerning the difference among these contexts, it is important highlighting that whereas (s), (i) and (o) has represented the classical security agents, (c) and (e) correspond to contexts especially relevant in the nowadays global society. Until the 1970s, the equilibrium among (s), (i) and (o) has been achieved - despite the prevalence of accumulation of power - by means of constant economic growth (considered by Rostow (1960) as an unlimited mechanism). This growth brought about two relevant consequences: on the one hand, it directly corresponded to the broadening of its eco-systemic basis, which limits started to be evident from the decade of $1970 ;{ }^{20}$ on the other hand, it impelled the increase of international migratory flows and land migrants to the cities which turned the relatively homogenous societies at the beginning of the $20^{\text {th }}$ century into complex societal systems characterized by a plurality of agents, goals, beliefs, etc. ${ }^{21}$

These two facts change radically the genuine horizon of the achievement of security towards the contexts denoted by (c) and (e). However, the agency of the first kind of contexts is still essential, since it is within the states and their international interplay where the attained historical and fragile security, the contingent equilibria, as well as the achieved emancipations are substantiated. Nevertheless, after centuries of growth under geographical colonization and below the biospherical limits, there is growing evidence that the pursuit of securities of type 1 are intrinsically unstable, and the authentic horizon of security is within the boundaries of $(\mathrm{e} 2)$ and shall be attained in (c2).

\subsection{The Liberalistic Vision of Security}

From the point of view of classical liberalist doctrines, the realm of security is chiefly restricted to (s1), (i1), (o1) and (e1). It corresponds to what we have named (section 1.1.3) the settling of the liberal frame, or Locke's "frame of government" (see note 9) - trust is bounded by this frame, which individualistic groundings are specially preserved by (i1). However, (o2) and (c1) can also be foreseen, though restrictedly, for some liberalist authors as the procurement of essential assets of general interest - from the point of view of the state - that cannot be achieved otherwise. ${ }^{22}$

\footnotetext{
${ }^{19}$ It corresponds to settling the frame in which modern economics is developed as criticized by Polanyi in terms of 'formal economy' (1957). The relation between (s1) and (e1) has often been underlined in relation to historical wars as the aforementioned opium wars, the Iraq wars - as we did above - but also in many other military conflicts, e.g. Afghanistan or Colombia (Klare 2002).

${ }^{20}$ As stated by the Club of Rome (Meadows et al 1972) and several scientific analysis, e.g. the works of Commoner, Boulding, Georgescu-Roegen, or Daly appearing during the 1960 s and 1970 s

${ }^{21}$ The migratory population duplicated between 1965 and 1990, the rate of urban citizens has grown constantly, becoming globally predominant since 2007 (Blandine 2010).

${ }^{22}$ That is, the private initiative cannot provide them. E.g. education, administration of justice or defense in Smith (1776, $\S 3)$, or many other areas in Bentham's or Mill's radical liberalism.

It should be noticed that the liberalistic achievement of a general interest - of national or regional scope - in complex societies can not be regarded as (c2), since the latter is not based on the global equilibrium of goals in the international complex system, not closed by national or regional boundaries (even in the case of the universities understood as a part of the global system of science). For instance, the promotion of the American Communication and Cultural Industry -
} 
As we can see in Smith's groundings of liberalisms all the strives towards security in any of the above contexts in their second senses (x2) and especially in (c2) and (e2) are explicitly excluded:

"The sovereign is completely discharged from a duty, in the attempting to perform which he must always be exposed to innumerable delusions, and for the proper performance of which, no human wisdom or knowledge could ever be sufficient; the duty of superintending the industry of private people, and of directing it towards the employments most suitable to the interests of the society" (Smith, 1776, p.407).

The honesty of this exclusion lays on the limits of the methodological individualism - referred above (section 1.2): by means of the practically unlimited combination of free intentions and the involvement of innumerous factors in its deployment, we are unable to grasp and predict the particular dynamics of the set of interactions.

However, from this liberalistic groundings, there has been growing awareness - specially since 9/11 - of the possible conflicts arisen between (i1) and either (s1) or (o1), since the deployment of the security of these can threaten the sacred principle of inviolability of privacy. This is clearly the problem of both heteronomous security and the limitation of state interventionism, which has a long historical presence since the appearance of the conservative liberalism in the $18^{\text {th }}$ century (Mellón 1998).

In the foundations of liberalism, the avoidance of the privacy violation - though fundamental - is not a categorical value, but limited by the possibility that privacy was used to conspire against others, or the whole. Hence there is a common acceptance of this violation of privacy if general security is threatened or another private security is unfairly exposed. However, in the other extreme, if a national or private security system stresses its measures to proactively grant its own interests, regardless the privacy of others, the conflict is settled and violation of privacy might exceed acceptable limits. In this case, trust cannot be maintained and the liberalistic frame is threatened, therefore an equilibrium is needed for required procurement of trust.

Furthermore, when this privacy violation belongs to completely alien interests, for instance, the surveillance by another state or commercial company intending to grant dominance against one's interests, the rejection is categorical whenever this conflict of interests is grasped (Chomsky 2003). Therefore the occultation of these practices within the liberal states is one of their essential elements - as it is the case of the Echelon and Franchelon Networks or Israel's 8200 Unit for strategic surveillance (Mattelart 2003, Hager 2010).

Although an increasing awareness has been stated in the last decades concerning these excesses, particularly in the individual-, private-, or minority surveillance after 9/11 (Norris \& Armstrong 1999, Lyon 2002, Wood and Ball 2006, Webb 2007, Zureik et al 2010), it is symptomatic of the liberalistic accepted equilibrium between surveillance and privacy that often the distrust on the surveillance technologies does not have arisen from a rejection of the violation of privacy, or the unfairness of the related dominancy, but from the utilitarian verification of a negative balance regarding the expected results. This has been for instance the case of the stressed practice of video-surveillance and other remote monitoring practices during the last 15 years (specially in the US and EU, though asymmetrically distributed among countries), which negative balance in the private, economical and criminological spheres (abuses, expenses and increase of crime) has been stated in several impacts assessing in UK and other EU countries (Ditton 1999, Gill 2005, Leblanc 2008, Smith 2004). ${ }^{23}$ Also often utilitarian reasons assist the critics of the commercial surveillance on the Internet - in spite of the growing evidence that privacy is violated and new

discussed in section 1.1 - can be regarded as a case of (c1) since such system is: (i) part of the American social system and also the global cultural industry, (ii) it is crossed with international relations and blended with other cultural systems, and, furthermore, (iii) it serves to the particular goal of cultural dominancy instead of the equilibrium of interests in the global complex system.

${ }^{23}$ Despite this relative distrust and the evidences of the assessments, there has been a practical maintenance of the surveillance policies driven by the states condemned by the mentioned authors. 
relations of domination appear, for instance in the labour sphere (Le Crosnier 2008, Story 2007, Fuchs 2009a).

In sum, the liberalistic attainment of security is based upon the equilibrium of (s1) - (i1) - (01) (e1), and the restricted and variable addition of (s2) - (o2) for governance assurance (namely, a minimum of trust) and (c1) for the achievement of dominance. However since this security procurement is antagonist to the one pursued by other states, alliances, regions, ecosystems... the conflict is unavoidable under this frame, thus global security requires another stage. One of the posed solutions - during the past two decades specially until 2008 - was unipolar dominance, namely hegemony, though the security achievements concerning peace, trust, political and economical stability were significantly poor, whereas the growth of the clefs between countries, social groups, rich and poor (Atkinson 2009, Milanovic 2007, Gresh et al 2004, 2009) as well as dissonances in the environmental and societal sustainability reached unprecedented scores (Bovet et al 2008).

\subsection{Beyond a Liberalistic Account of Security in the Information Society}

In the previous analysis of security and the critique of the liberalistic uses, we have set a normative stage allowing to distinguish between good and bad uses of security, and to foster good security. We posed some limits to what we called a genuine security in section 2.3 , arguing that (e2) puts the boundaries within which security can be achieved, and that (c2) constitutes the context to achieve it; and furthermore, rejecting security of type 1 due to its aporetic character.

If we consider information systems (constituted by Information and Communication Technologies, and considered as essential elements of the Information society) it is worth pointing out that - despite the promises of support of a fair, democratic, participatory, and non-polluting society - the age of deployment of these technologies has been coincident with: (i) an increasing weight in the economical, social and political organization; (ii) an increase of consumption goods and productivity (Gresh et al 2009) (iii) an intensification of inequality and poverty, the decrease in the political participation and the increase of pollution and energetic consumption (Atkinson 2009, Feilhauer and Zehle 2009). Though this situation is, of course, the result of a vast combination of factors, it is a clear symptom of the failure of technological determinism, and the necessity of a more fair economy (beyond the reduction of the digital divide) for harvesting general economic and social benefits from new technologies. ${ }^{24}$

As argued above, since information systems are subsystems of the information society - a clear case of complex societal system -, the security related to the achievement of goals just determined by the information subsystem is not enough. In its place, a sustainability concerning the information society attainable within (e2) and (c2) is the reasonable horizon of security as an effective warranty of trust as it has been posed by several authors (Hofkirchner 2007, Fuchs 2009b, Kukuda-Arr 2001, Wolff 2002, Logan 2010). For the search of an equilibrium in the context of (c2) related to the information society covering ethical, economical, social, political and environmental concerns, the field of information ecology has been developed since Capurro's proposal at the beginning of the 1990s (Capurro 1990, 2009, Floridi 1999, Hofkirchner 2007, Logan 2010). ${ }^{25}$ But in addition to this field, the attainment of (c2) needs also jumping over the boundaries set by the liberalistic horizon namely a critical theoretical approach aimed at pursuing the fulfillment of the promises of the enlightenment (Fuchs 2010). Informational assets have to be evaluated in relation to all other societal process within the complex international societal system, closed by the Earth biosphere.

Furthermore, we must find a feasible methodological path, not only to pose the goals of security or to analyze security measures but to achieve security in the sense of: enabling the pursuit of goals shared or fitted to the global functioning of the complex system (c2) and the administration of resources with respect to general needs as to warranty its future and general fulfillment (e2). The

\footnotetext{
${ }^{24}$ as acknowledged by the inquiries of international agencies as UN, OECD, World Bank, etc (s. Milanovic 2007)

${ }^{25}$ The need for an interdisciplinary approach to security concerns has also been stressed by the recommendations especially 1 and 2 - of the report "Trust in the Information Society" to the European Commission (RISEPTIS 2009).
} 
challenge corresponds to the extent and complexity of the relations constituting the whole system, whose understanding was prima facie rejected by liberalist methodology.

\section{An Informational Systems Approach}

\subsection{A Paradigmatical Systems Approach to Security: Cybersyn Project}

Before deploying our approach to security, in the sense that we clarified in the previous section as positive or genuine security, namely the attainment and support of global, sustainable and general positive freedom, it will be useful to recall a historical case in which the methodological paths to security followed an antagonist counterpart to the liberalistic approach - at least the dominant one during the last decades. We refer to the case of the implemented cybernetic control of the nationalized economic companies by Allende's government of Popular Unity in Chile during the years of 1972 and 1973. Such economic control proved its strengths against the "soft" power organizing the massive transport strike but it brutally collapsed under the bombs of the hard power in the other black 9/11 of 1973 (Church 1975, Atina 2008, Rivière 2010).

The project CyberSyn was initiated in 1971 by the invitation to the British cybernetician Stanford Beer by the National Company Corfo, who enthusiastically accepted. The objective of the project directed by Fernando Flores, Beer and Raúl Espejo - was the implementation - at the national level - of the scientific approaches of organization and management to cope in real time with the economic crisis by means of a coordination of actions under the monitoring of the information from all the related national companies. To dissipate any Orwellian interpretation, it is worth highlighting Allende's insistent claim to ensure that the system behaves in a "decentralising, workerparticipative, and antibureaucratic manner" (Medina 2008).

The CyberSyn team integrated by scientists of different disciplines deployed a well organized information network - though based upon very limited technological resources - as a backbone of the controlling system at national scale. Figure 2 shows the "Viable System Model" (VSM) that the project intended to implement.

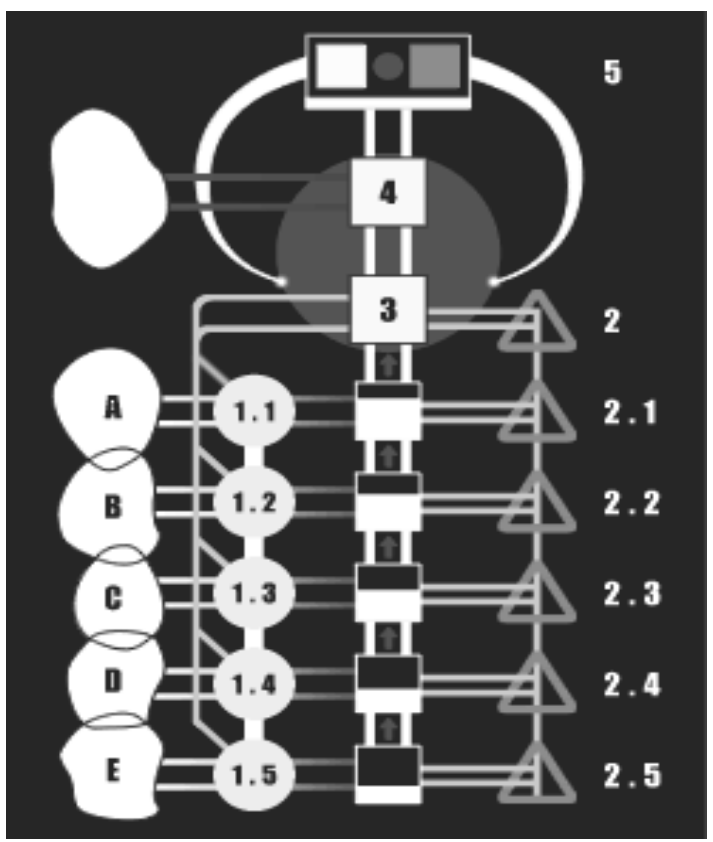

Figure 2: Schema of CyberSyn's Viable System Model. Clouds on the left: environment (A-E organizational, global at the top); 1 : primary activities; 2 : information channels; 3 : current internal management; 4: environmental and future monitoring; 5 : political decisions of the organization aimed at balancing global necessities (OR-AM 2006). 
The VSM allegedly structures the organization of any viable system, i.e. any organized system that combines the survival demands in a changing environment. It consists of 3 different states that incubate the management and dynamics of the processes at: (a) the environment of the organism; (b) the operations area, (c) the metasystem. As illustrated, the system is integrated by the following subsystems: activity, information, internal management, environmental monitoring and global management; and there are 5 control and information levels.

Although the systems could not be fully implemented, in October 1972, the CyberSyn team faced the truck strike - supported by the CIA and the US 40 Committee (Church 1975). CyberSyn endeavored organizing the 200 loyal truckers (against 40.000 in strike) to warranty the most essential transports. The survival to this crisis made the project respectful. Furthermore, Flores was appointed as Economic Minister. Pitifully, as said above and before the project could be fully developed, the bombs and guns of the hard power finished the experiment in the 9/11 of 1973, and Flores spent three years in the concentration camps of Pinochet's Chile (Rivière 2010).

The probe that, from the viewpoint of security as freedom procurement - as we previously posed -, the CyberSyn project was a clear example of it, is based upon the following facts: (i) the political, social and economical stability was dramatically threaten during the period of development of the project, (ii) it enabled the circumvention of extreme harms, and (iii) it was posed as a provision of freedom (Medina 2008).

\subsection{A Methodological Shift}

The lacks of the methodological individualism can be considered bringing back the example we posed at the beginning, concerning the stability of the solar system. The fact that the planets are so far apart, helped Newton's method of analyzing the forces between gravitational pairs of bodies to succeed in the prediction of the planetary dynamics as if they were mere points in the space interacting with another point concentrating a large amount of mass. As he recognized, the consideration for instance of the huge Jupiter to analyze the Earth dynamics was not feasible by his method. If we had lived in a more diffuse planetary system, probably Newton's dynamics would not be so successful - at least it would not have caused such an astonishment.

Instead of considering the action at a distance between pairs of bodies, Laplace started regarding the modification of the environment - plain space - by a massive point, which could be extended, in virtue of the linearity of the involved differential equations, to the modification of the environment by any system of masses. By those means, the road was opened to analyze the dynamics of the solar system not as combination of pairs of forces at a distance, but as due to the interactions among all its parts. Furthermore, analyzing the exact dynamics was still hard - actually it needs a large amount of information, describing the system too in detail, and entailing complex mathematics -, however analyzing the stability, as he did, was feasible (Godunov 1978: §1).

The formal parallelism between Newton's gravitational interaction of two bodies acting at a distance and the above mentioned liberalistic model of trustworthiness (section 1.2) is easy to observe - despite the evident material differences. Newton's or Adam Smith's recognized limitations of their own analytical methods were honest and parallel as well. However, even recognizing the relative correctness of their explanatory stances, what cannot straightforward be admitted is the unfeasibility of analyzing a more complex combination of relationships, as it is the case of planetary systems or economic and social systems.

Furthermore, there are good reasons to state important limitations of their assumptions, which make their models only applicable under certain restrictions. But if Newton was fairly right making the approximation of not considering Jupiter in order to analyze the dynamics of the Earth, in the social context, the assumptions of the methodological individualism are far from being acceptable, if we intend to understand the social reality. Or what can be even worse, artificially making the assumptions approximate enough will embrace such mutilation of the human reality that we could hardly recognize it (Aron 1989, $\S \mathrm{XV}, \mathrm{XVI}$ ). 
If we delve into the methodological approach to the security and control of systems that could be branded as liberalistic, we find the intention to reduce the complexity of the system by dividing it into subsystems only interacting with the ones at the same level or laying at the immediate hierarchical ones (e.g. OSI layers, levels of the W3C standard). These interactions are intendedly mediated by protocols and the boundaries of each subsystem so well defined as to make the subsystem interchangeable by any other of the same type (INTECO 2010). The possibilities of commodification of the whole are clear enough as to need further clarification - it is this possibility and the methodological reduction of simple interactions that enable us to brand this approach as liberalistic. However the limits of this approach have been posed in virtue of efficiency lacks, whereas vertical integration starts to be claimed, particularly at the level of large scale infrastructures which reliability is critical - despite earlier trends of modularization (ESFRI 2008).

A shift in the possibilities to deal with the complexity of systems that are constituted by a large set of relationships was stated, among others, by Ross Ashby (1956):

"For two centuries it has been exploring systems that are either intrinsically simple or that are capable of being analysed into simple components. The fact that such a dogma as "vary the factors one at a time" could be accepted for a century, shows that scientists were largely concerned in investigating such systems as allowed this method; for this method is often fundamentally impossible in the complex systems. [... But] there are complex systems that just do not allow the varying of only one factor at a time - they are so dynamic and interconnected that the alteration of one factor immediately acts as cause to evoke alterations in others, perhaps in a great many others." (p. 5)

What the systems approach offers is the possibility "of providing effective methods for the study, and control, of systems that are intrinsically extremely complex." (pp. 4-5)

\subsection{Actualizing the System Model}

We have made explicit our advocacy for a systems approach to security, and we have pointed out the lacks of the principles and methods of the liberalistic approach. The example of the CyberSyn project in Chile in the 1970s serves us as paradigm. However, some changes have been produced since then in the international economics, politics and societies making necessary the actualization of the system approach depicted by Beer's Viable System Model (VSM) - see fig. 2.

In section 2.3, we posed that the context of national states as the level for the attainment of security - in which CyberSyn was deployed, namely (s2) - has to be superseded in order to situate it into the complex societal system scenario, namely (c2), which is bounded by the Earth ecosystem (e2) ${ }^{26}$ Furthermore, the tragic ending of the project and the external interventionism probes the need to attain security at these contexts, conceiving (c2) at the international level. ${ }^{27}$

At first glance, a systems approach to security - in the sense we posed above as mostly adequate for the real complexity of social system and its long-term sustainability - embraces:

(1) systems that are open, though ultimately closed by the biosphere, and cognitive. The earth ecosystem within its stable limits - i.e. the set of states within which any variation is reversible - sets the ultimate boundaries of any other system. Its feed of low entropic energy sets the limit of available energy; its high-entropic energy release limits the affordable waste.

\footnotetext{
${ }^{26}$ As briefly discussed above, the VSM was intended to cope with complex societal systems, and the level 4 was intended to cope with environmental needs and limits in a long-term basis. However, the complexity of the societal system is now of higher order and the closure of the ecosystemical dimension is now tighter linked to the biosphere.

${ }^{27}$ The interventionist dimension of the US concerning alleged threats to their interests can be unambiguously observed in the Church Report of the US Senate (1975), "Did the threat to vital U.S. national security interests posed by the Presidency of Salvador Allende justify the several major covert attempts to prevent his accession to power? Three American Presidents and their senior advisors evidently thought so." Due to its international character, it unveils the dominancy criteria in US security issues.
} 
(2) System's ontology is defined by the set of components, structure - identified by relations among components -, and the environment in which it is immersed; System's pragmatics are defined by the set of functions and acts within the environment in interaction with other systems; ${ }^{28}$ System's epistemology is defined by the complexity and state of the cognitive subsystem.

(3) The security of a system at any level refers to the stable attainment of a sufficiently broad space of possibilities in which the system can cope in the long-term with environmental dynamics and its own necessities.

(4) The space of possibilities (or space of freedom) is defined by the region of the state space of the system in which the system can freely vary through alternative paths causing subsequent limited changes to the related systems (specially those at higher or at the same level).

Figure 3 provides a basic schema of a system in simple interaction with the environment. The diagram stresses the relevance of the information phenomena in (i) steering the system; (ii) interacting with the environment and other systems; and (iii) actualizing knowledge about the environment, other systems and the system itself.

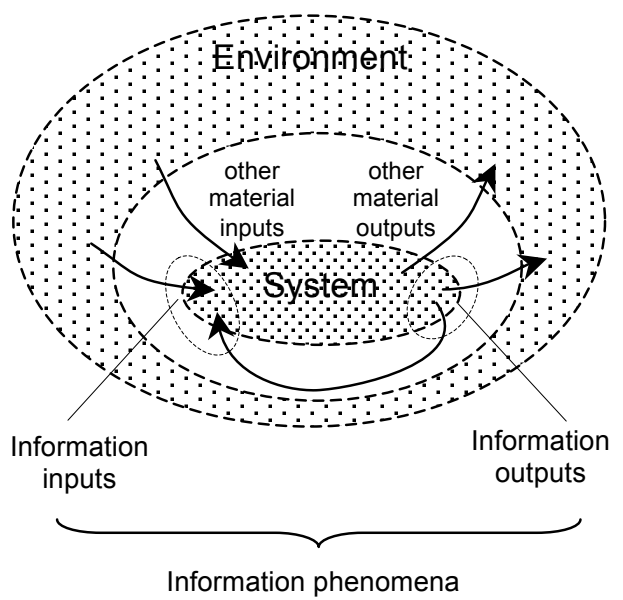

Figure 3: Simple system model of interaction with the environment. The dotted boundaries stand for the fuzziness of the system's limits. An outermost defined and closed boundary could be considered at the biospherical level in which the interaction with the outside is in the form of a lowentropic energy input and a high-entropic energy output. This model can serve for hierarchical systems in which lower level systems are nested.

But these elements alone do not enable to cope with the complexity of the global societal system closed by the Earth ecosystem. Thus some new characteristics have to be added:

(5) Sustainability: the limits and the space of renewable resources of our natural environments set the first space of freedom for the social systems. These have to accommodate their set of necessities and set of acts (including production) within the natural space of freedom to keep it balanced. Furthermore, this balance has to be attained before the point of diminishing returns in which adaptation becomes increasingly problematic, namely its carrying capacity (Street 1969, Turner 1997). Similarly, any social or technical system nested in another of higher order has to accommodate into the social space of freedom.

(6) Heterarchical organization: As pointed out in section 2.3. instead of hierarchical systems, in which lower order systems are nested into higher order ones, the actual complexity of societal

\footnotetext{
${ }^{28}$ The interaction with the environment and with other systems is distinguished because often the functional linkage among them makes the interactions particularly relevant with respect to other elements of the environment not functionally linked with the system. These interactions usually serve to some heterarchical organization.
} 
systems rather corresponds to heterarchies in which the component subsystems might belong to several systems. This is for instance the case of nervous systems, as first studied by McCulloch (1945). Since the relations of the parts of the heterarchy to one another are unranked or "possess the potential for being ranked in a number of different ways", this organization clearly challenges the CyberSyn model of fig.2, and increases the space of nonequilibrium to which security is concerned (Bondarenko 2007).

(7) Fuzzy system limits: A further problem regarding a proper grasping of the systems concerns their blurred limits (for instance, in the linguistic systems there are always elements that are in process of being incorporated to the flow of the used language; some others that are being lost, and others whose functions are changing). Although this issue is of higher relevance in the systems that are being formed, or are dying out, to some extent, this is the case of any system (even in the technical ones, in which often many characteristics are inherited by older configurations, have a diminished functionality, and they will be eventually removed). In our plea for a scenario of emancipation this regard is fundamental for envisaging the enabling of new systems to appear (De Paoli, Gangadharan et al 2010, Niizato and Gunji 2011).

Though all this makes the systems difficult to model and analyze (the given references provide some guidelines and proposals to do it), something remains easy to distinguish: if the system is secure within its environment it is in a stable condition, and the reactions to changes in the environment tend to compensate those changes.

As system theory and practice has proven, if proper relations are envisaged and procured, the stability of the system can be evaluated (as Laplace did) and granted (as the CyberSyn project showed), even though its particular dynamics (i.e. its evolution, its history) cannot be predicted since it properly depends on the free elections taken by the members within the space of freedom.

\subsubsection{Pillars of Security}

Let us remind again the case of security concerning the stability of the solar system - which stands for an extreme case of environment -. Our trust (or security) in the environment in which we are living - as it is the IS (Information Society), or it is intended to - cannot be reduced to the aforementioned liberalistic model of trust, namely we trust in the IS to do $X$ (section 1.2). 18 ${ }^{\text {th }}$ century peasants did not expect from the solar system any particular doing, they just wished a secure ground that enabled to do their lives. And this cosmological medium clearly constitutes a system of resources and limitations: the basic energetic sources, the high energetic radiation inhibiting any life, the gravity against which we have to stand up and the one which brings together the biosphere allowing our very lives. Synthetically, a set of possibilities and limitations.

Mutatis mutandis, the Information Society should also constitute a ground for making life, i.e. it should provide on a long-term basis enough resources (physical and logical) for tackling social necessities and it must be adapted to the inevitable limits bounding the space of acting. ${ }^{29}$ Thus renewal resources, necessities, limits and acting can be conceived as the four pillars of a secure and sustainable IS, illustrated in fig. 4. Instead of constituting static basis for the IS, these pillars rather conform a set of plastic antagonist pairs, which must be dynamically balanced.

On the contrary, if we cannot find a space of acting bounded to the given limitations, a set of necessities adapted to the renewal resources set by the carrying capacity (Turner 1997), etc., we can barely feel secure in such a system. In other words, we are positive and sustainable secure in our environment if (and only if) we (including latter generations) can make our lives in it and these lives are not mere survival but encompass a sufficiently broad space of possibilities.

\footnotetext{
${ }^{29}$ Information Society is here considered in a broad sense, not only considering those social systems in which the mediation of informational interchanges and the support of information technologies are tangibly dominant. Since also current societal systems without such tangible informational relevance are significantly dependant of the more technological advanced societies, they are also included in the global IS.
} 


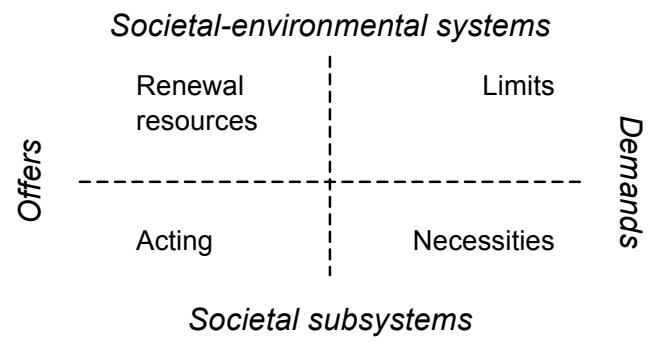

Figure 4: Four pillars of security

Instead of the personal surveillance in the liberalistic approach to security, which can be regarded as a logical consequence of the methodological individualism, in the systems approach the monitoring devoted to grant the security in the above proposed sense should grasp information about the environment and about the system to evaluate and steer: (i) the general attainment of necessities properly ranked with respect to its essentiality; (ii) the balance of available renewal resources with respect to the normal development of the social activities; (iii) the maintaining of a safe distance with respect to the environmental limits as to provide enough renewal resources in a long term basis.

\subsubsection{The Central Role of Information}

Since the beginning of System Science and Cybernetics, the importance of information has been central. This relevance was for instance stated by Ashby defining the field as "the study of systems that are open to energy but closed to information and control systems that are "information tight" $(1956: 4){ }^{30}$

However, our stress on information as to speak about informational Systems Approach, is not due to the purpose of reducing our scope only to systems interchanging information, but referred to the fact of the centrality gained by information during the last two decades, not only as a means of regulating the system, its incomes and outcomes, but also as the central mechanism of interaction.

Comparatively, the importance of information processes have significantly increased since the time of CyberSyn: on the one hand, the informational outputs are now an essential - and often dominant - part of the production; on the other hand, the informational flows have grown in both extension and intension, feeding more complex cognitive process.

In a very broad sense and using the General Theory of Information (GTI) posed by Mark Burgin, information is regarded as "information for a system" and referred to the "capacity to causes changes in" the system (Burgin 2010, pp. 123-124). This concept implies relativizing information (first part) and giving it a tangible ontological value (second part). According to this conception, it is information the very responsible of system dynamics, and even energy "is a kind of information" referred to physical systems (p. 124). In the case of cognitive systems, which are modeled in the GTI by Infological Systems, information represents the possibility of actualizing cognition or knowledge.

In any case, it must be underlined that - albeit the relevance of information in the dynamics of the system - its functioning is by no means reducible to informational processes.

This vision of information enables, for instance, a review of labour, which is of security relevance in our information societies as pointed out in section 1.1.4. The classical regard for work forces, work power and work, has a rather physical nuance: work/energy is required by any change/movement in the productive/physical system. Labour contracts deal with work forces, i.e.

\footnotetext{
${ }^{30}$ A similar stress on information can be generally found in many other System scientists, e.g. Wiener, Bertalanffy, Boulding, Bateson, etc.
} 
the productive offer of a worker; its use in productive process is the work corresponding to the interests at stake; and the capability of producing sufficiently fast concerns the ability to intensify work in time, namely productive power. The attainment of the latter corresponds to the ability to cope with competition, essential to succeed in the capitalistic enterprise.

The basic means to achieve productive power are: increasing the forces by widening the labour basis; and intensify the forces represented by each worker by organizational and technical means. This swift outlook implies, in one sense, the interchangeability and plasticity of work corresponding to the relative homogeneity of the working class at the beginning of the $20^{\text {th }}$ century, but in the other, its non reusability, i.e. a unit of work is obtained by a unit of productive force deployed in a unit of change (translated into a unit of production), and this unit of work is spent by using it. In other words, the productive force needs to be reactualized, recovered, maintained, and it inalienably belongs to the worker him/herself. Furthermore, increasing productive power in technological continuity used to be increasing the weight of the working class.

When the cybernetician Norbert Wiener tried to prevent Trade Unions concerning the dangers of automation, he implicitly referred to the possibility of losing the ultimate strength of workers in the balance of capitalist democracies (Noble 1993), because what information technologies change is the possibility to accumulate an extreme productive power, based upon the practically costless reproducibility of information (Fleissner 2009).

If we recall the aforementioned general definition of information, the possibility to make information as a fundamental factor of power productivity attached to capitalistic interest requires several conditions: (i) by its practically costless reproducibility, information conserves its productive power - even after being used - only if there are more systems that are equally changeable (the stress on normalization of products, devices and audiences in liberal societies can be interpreted as a means to obtain this condition); (ii) the concept of production has to be shifted to allow the redistribution of profit intensifying the step in which the productive force is multiplied by copying this requires the appropriation of information as a fundamental asset which has to be protected, as it is in the kernel of the struggles concerning copyright laws or the General Agreement on Trade in Services (GATS) in the WTO. ${ }^{31}$

The knowledge base, or the information supported by such knowledge in order to drive the general procurement of needed goods, has been cherished in modernity as a fundamental public asset (it can indeed be regarded as the base of enlightenment), but what the new informational economy posed - at the capitalist side - is its appropriation, which social consequences can be dramatic and deep: First, the necessity to reproduce systems globally - condition (i) - is in opposition to the necessity of adapting them to the fundamentally closed earth ecosystem; second, the appropriation of the knowledge base represents a concentration of power which extensively hinders the attainment of freedom; third, it corresponds to an almost costless re-appropriation of a public, immeasurable and invaluable good by the private sector; forth, the possibility of collapsing the scientific enterprise as an open and public production. ${ }^{32}$

If the analysis is correct, these consequences of the capitalist appropriation of the knowledge base highlight what is a must on our information societies, as well as a specific interest of the misrepresented societal sectors: the need to maintain knowledge at the public sphere, and the fair redistribution of the whole productive process in which information play a protagonist role.

Concerning productive processes - and by extension economics as whole -, the general information concept of the GTI can even serve as a refinement of the ideas of productive- forces, work and power. The aforementioned physical parallelism of these concepts has the hindrance of not grasping the whole process of production. As known, it is the means of production the factor

\footnotetext{
${ }^{31}$ As posed by Peter Fleissner, the understanding of the process of commodification of knowledge and information assets can be facilitated by a different concept of productivity, namely productivity (3): "the first notion of productivity is related to human beings who produce values in use, the second is linked to the production of reified values in exchange, and the third one with the attraction of profits associated to applied labour' (Fleissner 2009, p. 233)

32 The related concentration of benefits has been statistically confirmed during the period of deployment of the information economy in the last three decades (e.g. Gresh et al 2009).
} 
that had to complement labor forces for acting within the productive relations to explain the whole productive process: the low entropic energy of the working power had to be conduced (informed) to produce the desired changes (goods), however some balance between productive work and means was attainable when the importance of the relative "blind" working forces were important enough.

Now that the weak balance has been broken because the rate of labor as understood in industrial economies has been minimized and dispersed (as argued in section 1.1.4), generalizing information as the effective productive factor (covering both productive- labor and means) that act within an specific economic system (determined by the productive relations) might be an opportunity to enable the redistribution required to cope with social sustainability and to forward a participatory information society. It is the current possibility to act (informatively) on the global productive system - much more flexible than ever before - that gives information itself and information technologies an unprecedented power. On one side, to produce goods, but on the other, to cause changes in the very productive system. ${ }^{33}$

Like at any other time, the given productive relations and the strive for preserving the current power and dominancy will try to content the possibilities of change of these new informational productive forces (Marx 1859; Marcelo 2006). Recalling fig. 1, the tension between the possibilities open at the information society and the objective to contain them corresponds to an antagonist pair of forces, oriented either vertically or diagonally between top-left and bottom-right, depending on political options (as discussed in section 1.1.3). The movement towards one or the other direction depends, among others, on the awareness of the objective possibilities by the involved subjects.

\subsubsection{Information and the Objective vs. Subjective Values of Security}

As we considered at the beginning - in the example of the stability of the solar system, or later on, in our analysis of security senses (section 2.2) -, security involves objective and subjective values. The difficulty to reconcile them concerns, among others, the fundamental difference between the outer and inner perspectives, which presupposes a different ontological and epistemological position through which cybernetics has historically moved (Díaz 2010b). Ontologically because we form part of the system we are interested in; epistemologically because we cannot observe the point from which we observe. Furthermore, the openness of the systems (represented by doted lines in fig.3) implies that even if we observe the environment, our possibility of modifying it makes that the combination of environment and system forms a system of higher order, and we actually steer both at a time - though in a different degree. Thus the goals of a system have to be immersed into the ones of the higher order system.

This means assuming a common ground of what has been called second order cybernetics: the objective and subjective perspectives are mutually dependant and the system cannot be clearly separated from its environment, as it happens in living systems and even more in human and social systems.

One of the consequences of this limitation - namely the unfeasibility of a neutral observation makes the Laplacian certainty concerning security out of reach. Thus, security can only be granted to a given extent and needs to be constantly re-actualized while the system is steered in equilibrium with the steering of the systems of the higher and same order, i.e. within the whole

\footnotetext{
${ }^{33}$ Such rupture of the "weak" balance between productive- forces and means within the liberal democracies endangers for instance the mutuality character, allegedly attributed by classical liberalism to division of labor, which relative loss is evidenced by the uninterrupted growing inequality during the last decades. As Fleissner shows (2011), the methodological assumptions of liberalism concerning the achieved mutuality at the equilibrium of individual (and selfish) strives cannot be stated at the given complexity of the economic systems; instead, the role of the different economic factors and agents can be rather integrated in the whole economic systems superseding the methodological individualism -as argued above-. To this end, he proposes a systematic model composed by different interweaved layers from physical basis to informational economy, which also admits an historical interpretation. The dynamical composition of all these layers allows to express the observed market as an overarching layer. Based upon this dynamic account of economic factors and agents, he shows that "an increased wellbeing of the many instead of maximizing the wealth of the few" needs "to establish a new political institution which is able to take over control of all layers."
} 
complex societal system closed by the Earth ecosystem. It is easy to see that this idea is actually not very far apart from the concept of the CyberSin's Viable System Model.

But to this point, it is worth delving into the characteristics of our awareness of the environment upon which the steering of the system for security attainment is founded. As we have analyzed elsewhere (Díaz and Pérez-Montoro 2011a, 2011b; Al Hadithi and Díaz 2010b) the awareness of the suitable conditions of our environment is constitutively limited and blurred in virtue of the physical nature of the manifestation of reality. This means that in order to assess the environmental conditions and to foresee future conditions, we must deal with:

(1) the open character of the reality being sensed;

(2) the limitation and fuzziness: $1^{\text {st }}$, of the manifestation of such reality, $2^{\text {nd }}$, of our awareness of reality, and $3^{\text {rd }}$, of our knowledge. ${ }^{34}$

Using the concept of information posed by the GTI, the process of awareness can be studied by means of the action of information upon infological systems and the triadic relation established by the Environment, information and the Infological system (Burgin 2010). From our analysis of the dimensional relations among the parts of this triad (Díaz and Pérez-Montoro 2011b): the maximal complexity of an observed system has one dimension more than the maximal dimension of any informational process related to the observation. Thus we have to conclude the imponderability of the knowledge base with respect to the weight of information in the whole awareness process.

Again, the role of the social assets corresponding to the cultural and scientific base, education, and research has to be brought to the forefront in order to unveil its value in the economics, and in the attainment of social security. Moreover, as underlined in the previous section, a fair and participatory society requires keeping those assets in the public sphere circumventing the appropriation by the private sector.

But considering once more the aforementioned limited, open, and fuzzy character of our awareness and knowledge, it can be pointed out that the infological system modeling our cognitive process, or serving as a control mechanism for steering the system should correspondingly keep these characters. Therefore a fuzzy and paraconsistent calculus (adapted to the reality of our knowledge) based upon the information grasped - as indicated in 3.3.1 - should drive the security procurement of the complex societal system (s. Al Hadithi and Díaz 2010b, Priest and Tanaka 2009).

Far from being a hindrance to the achievement of stability, this kind of control has shown a higher degree of robustness (Al Hadithi 2002).

Furthermore, the posed limitations of our knowledge and awareness of reality implies - beyond a permanent adaptation of our knowledge base to the attained evidences - that our balance of necessities and resources has to be permanently actualized and reviewed by an ethical and critical concern for all social interests and their related threatens in a sustainable horizon.

\section{Conclusion}

Proven - in historical perspective - the inconsistency of the liberalistic discourse concerning security and trust, and unveiled the dominancy strategy behind this discourse, we observed the possibility to broaden the political postures concerning security and fairness - even at the liberalistic groundings. We also showed the limits of the liberalistic concept and methodology for the attainment of security and trust, which was later on contrasted with the systems concept and methodology.

The limits observed at the liberalistic approach, led us to discuss a more general sense of security, analyzing its elements and the contexts in which different security issues appear. We posed as genuine horizon of security: the stable and long-term sustainable attainment of general positive freedom.

\footnotetext{
${ }^{34}$ These structural ambiguities of reality, on the one hand, and our sensible intellection of reality, on the other hand, have been studied from the physical-mathematical, biological and cognitive perspectives (Díaz \& Pérez-Montoro 2011a, 2011b, Díaz \& Hadithi 2010b).
} 
Recalling the approach to security successfully implemented by Allende's ill-fated government of Chile in the early 1970s, we introduced a methodology beyond liberalistic groundings, analyzing the needs to actualize the model in order to cope with: the complexity of the societal system, the necessity to attain security at the global stage, the closure of the system at the biospherical level, the growing relevance of informational phenomena, and the essential limitation of our knowledge and awareness.

We observed the flexibility of the general theory of information for the understanding of system dynamics in a broad perspective, observing for instance the possibility to erect with its aid a critical stance in economic issues. This broad vision of information, involved in systems dynamics, provides a road to analyze and procure the security of complex societal systems in the posed sense. While the statics of the system are chiefly defined by their constitutive relations, its variation can be fundamentally understood as informational processes. In short: the system is "informed" by the environment and itself, reacting by structural and functional variations that are not reducible to mere causes of the information, and subsequently, it "informs" the environment and itself.

Finally the necessity to maintain a critical and ethical stance with regard to social issues under a biospherical closure was advocated in virtue of essential cognitive limitations.

\section{References}

Abellán J. (1998) Liberalismo Clásico (de Locke a Constant). In Mellón, J.A. (Ed.), Ideologías y Movimientos Contemporáneos (pp. 13-46). Madrid: Tecnos.

Al Hadithi, B. (2002). Análisis de Estabilidad Global y Diseño de Sistema de Control Borroso (Global Stability Analysis and Design of Fuzzy Control System). Doctoral Thesis. Madrid: Universidad Politécnica de Madrid.

Al Hadithi, B. \& Díaz, J.M., (2010a). Self-Regulation vs. Automatic Regulation. In J.M. Díaz, F. Salto and M. Pérez-Montoro (Eds.), Glossarium BITri: Glossary of Concepts, Metaphors, Theories and Problems Concerning Information (pp. 372373). León: Universidad de León. Retrieved January 20, 2010, from http://glossarium. bitrum.unileon.es/glossary

Al Hadithi, B. \& Díaz, J.M., (2010b). Fuzzy Logic. In J.M. Díaz, F. Salto and M. Pérez-Montoro (Eds.), Glossarium BITri, op.cit (pp. 275-284).

Aron, R. (1989). Leçons sur l'Histoire. Paris: Éditions de Fallois.

Ashby, W. R. (1956). An Introduction to Cybernetics. London: Chapman \& Hall, London. Internet available (1999), retrieved March 26, 2008, from http://pcp.vub.ac.be/books/IntroCyb.pdf

Atina Chile (Team) (2008). La Historia del Proyecto "Cybersyn". La opinión, August 2008. Retrieved January 26, 2011, from http://www.laopinon.cl/admin/render/noticia/10505

Atkinson, A. B. (2009). Unequal Growth, Unequal Recession? OECD Observer, 270/271. Retrieved September 30, 2009, from http://www.oecdobserver.org/news/fullstory.php/aid/2751

Bentham, J. (1891). A Fragment on Government. Oxford: Clarendon. Retrieved December 22, 2010, from http://www.archive.org/details/afragmentongove02bentgoog

Bentham, J. (1995, orig. 1787). Panopticon. In Miran Bozovic (Ed.), The Panopticon Writings. London: Verso.

Bilgin, P. (2008). Critical Theory. In Paul Williams, op.cit., (pp. 89-102).

Blandine, C. (Ed.) (2010). Atlas de las Migraciones. Valencia: Fundación Mondiplo.

Bondarenko, D. M. (2007). Approaching "Complexity" in Anthropology and Complexity Studies: The Principles of Sociopolitical Organization and the Prospects for Bridging the Interdisciplinary Gap. E:CO 9(3), 62-74. Retrieved January 22, 2011, from http://emergentpublications.com/eco/ECO_papers/Issue_9_3_6_PH.pdf

Booth, K. (1991). Security and Emancipation. Review of International Studies, 17(4), 313-326.

Bovet, P., Rekacewicz, P., Sinaï, A., Vidal, D. (dir.) (2008). Atlas Medioambiental de Le Monde Diplomatique. Valencia: Cybermonde.

Bowles, S. (2007). Le Poing Invisible. Manière de Voir, 91, 6-10.

Bradbury, R. (1953). Fahrenheit 451. New York: Ballantine Books.

Burgin, M. (2010). Information Operators in Categorical Information Spaces. Information, 1(1), 119-152.

Buzan, B. (1983). People, States and Fear: The National Security Problem in International Relations. Brighton: Wheatsheaf.

Capurro, R. (1990). Towards an Information Ecology. In I. Wormell (Ed.), Information and Quality (pp. 122-139). London: Taylor Graham, Retrieved November 20, 2009, from http://www.capurro.de/nordinf.htm

Capurro, R. \& Díaz Nafría, J.M. (2010). Information Ethics. In J.M. Díaz, F. Salto and M. Pérez-Montoro (Eds.), Glossarium BITri, op.cit, (pp. 308-314).

Chang, H.-J. (2003). Unfree Global Markets. Le Monde Diplomatique English Edition, August 2003. Retrieved January 10, 2011, from http://mondediplo.com/2003/08/07chang 
Chomsky, N. (1994) World Orders Old and New. Cairo: The American University of Cairo Press.

Chomsky, N. (2003). Hegemony or Survival: America's Quest for Global Dominance. New York: Metropolitan Books.

Christensen, C. (2010). Wikileaks: Three Digital Myths. Le Monde Diplomatique English Edition, August, 2010. Retrieved January 24, 2010, from http://mondediplo.com/blogs/three-digital-myths

Church, F. (Chairman) (1975). Church Report: Covert Action in Chile 1963-1973. Select Committee To Study Governmental Operations With Respect to Intelligence Activities. Wahshington: U.S. Government Printing office 63-372. Retrieved January 26, 2011, from http://foia.state.gov/Reports/ChurchReport.asp

Cobden, R. (1857). China and the Attack on Canton. Speech to parliament. Retrieved January 10, 2011, from: http://en.wikisource.org/wiki/China_and_the_Attack_on_Canton

De Paoli, S., Gangadharan, G. R., Kerr, A., D’Andrea, V., Serrano, M, Botvich, D. \& McGibney, J. (2010). Toward Trust as Result. A Transdisciplinary Research Agenda for the 'Future Internet'. TripleC, 8(2), 121-123.

Deleuze, G. (1990). Post-Scriptum sur les Sociétés de Contrôle, in Pour- parlers (pp. 240-247). Paris: Minuit.

Díaz, J.M. (2010a). Report on "Trust in the Information Society". Retrieved December 20, 2010, from BITagora: http://wp.me/pzLBk-25

Díaz, J.M. (2010b). Cybernetics. In J.M. Díaz, F. Salto and M. Pérez-Montoro (Eds.), Glossarium BITri, op.cit (pp. 251-252).

Díaz, J.M. \& Pérez-Montoro, M. (2011a). Is Information a Sufficient Basis for Cognition? (Part 1). Triple C, 9, in press.

Díaz, J.M. \& Pérez-Montoro, M. (2011b). Is Information a Sufficient Basis for Cognition? (Part 2). Triple C, 9, in press.

Díaz-Salazar R.(2002). Sociedad Civil Mundial. In Díaz-Salazar (Ed.) Justicia Global (pp. 21-84). Barcelona: Icaria-Intermón Oxfam.

Ditton, J. \& Short, E. (1999). Yes It Works, No, It Doesn't: Comparing the Effects of Open-Street CCTV in Two Adjacent Town Centres, Airdrie and Glasgow. Scottish Centre for Criminology, Glasgow, p. 15.

Elster, J. (1983). Explaining Technical Change. Cambridge, UK: Cambridge University Press.

ESFRI (2008). European Roadmap for Research Infrastructures. European Strategy Forum on Research Infrastructures. Luxembourg: Official Publications of the European Communities.

Feilhauer, M. \& Soenke Zehle (eds.) (2009). Special issue: Ethics of Waste in the Information Society. International Review of Information Ethics, 11. Retrieved May 26, 2010, from http://www.i-r-i-e.net/issue11.htm

Fleissner, P. (2009). The "Commodification" of Knowledge in the Global Information Society. TripleC, 7(2), 228-238.

Fleissner, P. (2011). Reconstructing the Economy: A Methodological Journey from the Surface to the Essence and Back. TripleC 9 (in press). Preprint retrieved September 15, 2012, from: http://www.sciforum.net/presentation/350

Floridi, L. (1999). Information Ethics: On the Philosophical Foundation of Computer Ethics. Ethics and Information Technology, 1(1), 33-52. Retrieved November 10, 2009, from http://www.springerlink.com/content/u3888645r51377j3/

Foucault, M. (1980). The Eye of Power: A Conversation with Jean-Pierre Barou and Michelle Perrot. In Power/Knowledge: Selected Interviews and Other Writings, 1972-1977, Gordon, C. (Ed.), Gordon C., Marshall, L. , Mepham, J. \& Soper, K.(trans.). New York: Pantheon.

Fuchs, C. (2009a). Social Networking Sites and the Surveillance Society. A Critical Case Study of the Usage of studiVZ, Facebook, and MySpace by Students in Salzburg in the Context of Electronic Surveillance. Salzburg/Vienna: Research Group UTI. Retrieved November 10, 2009, from http://fuchs.icts.sbg.ac.at/SNS_Surveillance_Fuchs.pdf

Fuchs, C. (2009b). The Role of Income Inequality in a Multivariate Cross-National Analysis of the Digital Divide. Social Science Computer Review 27 (1), 41-58.

Fuchs, C. (2010). Critical Theory of Information, Communication, Media and Technology. In J.M. Díaz, F. Salto and M. Pérez-Montoro (Eds.), Glossarium BITri, op.cit, (pp. 238-251).

Gernet, J. (1996). A History of Chinese Civilization. Cambridge, UK: Cambridge University Press.

Gill, M. \& Spriggs, A. (2005). Assessing the Impact of CCTV. Home Office Research Study, $n^{\circ} 292$, London.

Godunov, S.(1978). Ecuaciones de la Física Matemática. Moscú: MIR.

Golub, P. S. (2006). Quand la Chine et l'Inde Dominaient le Monde. In Jusqu'où ira la Chine?, Manière de voir, 85, 8-11.

Gresh, A., Radvanyi, J., Rekacewicz, P., Samary, C. \& Vidal, D. (Eds.) (2004). El Atlas de Le Monde Diplomatique. Valencia: Cybermonde.

Gresh, A., Radvanyi, J., Rekacewicz, P., Samary, C. \& Vidal, D. (Eds.) (2009). El Atlas Geopolítico 2010. Valencia: Cybermonde.

Hager, N. (2010). Israel's Omniscient Ears. Le Monde Diplomatique English Edition, November 2010. Retrieved January 25, 2011, from http://mondediplo.com/2010/09/04israelbase

Harper, D. (2001). Online Etymology Dictionary. Retrieved January 24, 2011, from http://www.etymonline.com

Hofkirchner, W. (2007). A Critical Social Systems View of the Internet. Philosophy of the Social Sciences, 37(4), 471-500.

Hugo, V. (1985). The Sack of the Summer Palace. Letter to Captain Butler. UNESCO Courier, 38 (November 1985), 15. Retrieved January 13, 2011, from http://unesdoc.unesco.org/images/0006/000669/066943eo.pdf

Huxley, A. (1932). Brave New World. London: Chatto and Windus. 
INTECO (2010). Information Security Taxonomy Handbook. León, Spain: National Institute for Communication and Communication Technologies.

Johnson, G. (2010). Military Budget. Info. Retrieved January 14, 2011, from http://www.militarybudget.info

Jones, W. (1999). Security, Strategy and Critical Theory. Boulder, Colorado: Lynne Rienner.

Klare, M. (2002). United States: Energy and Strategy. Le Monde Diplomatique English Edition, November 2002. Retrieved January 26, 2011, from http://mondediplo.com/2002/11/02energy

Kukuda-Arr, S. (Ed.) (2001). Mettre les Nouvelles Technologies au Service du Developpement Humain, Rapport Mondial sur le Developpement Humain 2001. United Nations Development Programme (UNDP), Nueva York: De Boeck \& Larcier.

Kullenberg, C. \& Palmås K. (2008). Contagiontology. Glänta 4/2008. Retrieved January 14, 2011, from http://www.eurozine.com/articles/2009-03-09-kullenberg-en.html

Lafourcade, F. (2007). Le Chaos Irakien. Paris: La Découverte.

Lao-Tse (1995). The Tao Teh King, or the Tao and its Characteristics, James Legge (transl). Retrieved January 12, 2011, from Gutenberg Project: http://www.gutenberg.org/ebooks/216

Laplace, P.-S. (1990). Traité de Mécanique Céleste. Paris: Jacques Gabay

Latour, B. (2005). Reassembling the Social: An Introduction to Actor-Network-Theory. Oxford: Oxford University Press.

Le Crosnier, H. (2008). Mouvements Tectoniques sur la Toile. Le Monde Diplomatique, 648, p.19.

Leblanc, N. (2008). Vidéosurveillance. Sous l'œil Myope des Cameras. Le Monde Diplomatique, 654, pp. 4-5

List, F. (1885). The National System of Political Economy. London: Longmans, Green and Co.

Locke, J. (1690 -orig.-, 2010). Second Treatise of Government. London: Awnsham Churchill. Retrieved December 22, 2010, from Project Gutenberg: http://www.gutenberg.org/files/7370/7370-h/7370-h.htm

Logan, R. (2010). Understanding New Media: Extending Marshall McLuhan. New Jersey: Hampton Press

Luhmann, N. (1979). Trust and Power. John Wiley \& Sons

Lyon, D. (ed.) (2002). Surveillance as Social Sorting: Privacy, Risk, and Digital Discrimination. New York: Routledge.

Marcelo, J. (2006). Nuevas Fuerzas Productivas Frente a Viejos Modos de Producción: Proletarios y Sociedad de la Información. Utopías, Nuestra Bandera: Revista de Debate Político, 2006(208), 37-73.

Marx, K. (1859 -orig.). Prologue. A Contribution to the Critique of Political Economy. Moscow: Progress Publishers, 1977. Also available in the Marxists Internet Archive. Retrieved January 20, 2011, from http://www.marxists.org/archive/marx/works/1859/critique-pol-economy/preface.htm

Marx, K. (1973). Grundrisse. Nicolaus (trans.). London: Penguin. Available at the Marxists Internet Archive. Retrieved January 22, 2011, from http://www.marxists.org/archive/marx/works/1857/grundrisse/index.htm

Maslow, A.H. (1943). A Theory of Human Motivation. Psychological Review, 50(4), 370-396.

Mastromatteo, E. (2010). Digital Divide. In J.M. Díaz, F. Salto, M. Pérez-Montoro (Eds.), Glossarium BITri, op.cit. (pp. 257258).

Mattelart, A. (2003). The Information Society: An Introduction. Thousand Oaks, California: Sage Publications.

McCulloch, W. (1945). A Heterarchy of Values Determined by the Topology of Nervous Nets. Bulletin of Mathematical Biophysics, 7, 89-93.

McKnight, D. H. \& Chervany, N. L. (1996) The Meanings of Trust. Retrieved December 20, 2010, from University of Minnesota: http://www.misrc.umn.edu/wpaper/wp96-04.htm

Meadows, D. H., Meadows, D. L., Randers, J. \& W. Behrens III (1972). The Limits to Growth. New York: Universe Books.

Medina, E. (2008). Designing Freedom, Regulating a Nation: Socialist Cybernetics in Allende's Chile. J. Lat. Amer. Stud. 38 , $571-606$

Mellón, J.A. (ed.) (1998). Ideologías y Movimientos Contemporáneos (pp. 13-46). Madrid: Tecnos

Miguel de Bustos, J.C. (1994). Sobre Comunicación y Desarrollo. Una Perspectiva Internacional. Afinidades, 5, 7-24.

Milanovic, B. (2007). Worlds Apart: Measuring International and Global Inequality. New Jersey: Princeton University Press.

Newton, I. (1729). General Scholium. The Mathematical Principles of Natural Philosophy, vol. 2, London.

Niizato, T. \& Gunji, Y-P. (2011). Are the Flocks Critical Phenomena? TripleC, 9 in press). Retrieved draft version December 20, 2010 from: http://www.sciforum.net/presentation/265

Noble, D. F. (1993). Automation Madness, or the Unautomatic History of Automation. Chicago: Charles H. Kerr.

Norris, C. \& Armstrong, G. (1999). CCTV and the Social Structuring of Surveillance. Crime Prevention Studies, vol. 10, Monsey (New York).

Nye, J. S. (2004). Soft Power. The Ways to Success in World Politics. New York: PublicAffairs.

OR-AM (2006). CyberSyn. Cybernetic Synergy. Chile: Art/Scicen Research Studio OR-AM. Retrieved January 26, 2011, from http://www.cybersyn.cl/ingles/cybersyn/index.html

Orwell, G. (orig. 1949, 2008). Nineteen Eighty-Four. London: Penguin. 
Paoli, S. De, Gangadharan, G. R., Kerr, A., D’Andrea, V., Serrano, M., Botvich, D. \& McGibney, J. (2010). Toward Trust as Result. A Transdisciplinary Research Agenda for the 'Future Internet'. TripleC, 8(2), 121-123. Retrieved December 20, 2010, from: http://triple-c.at/index.php/tripleC/article/view/213

PewGlobal (2003). How Global Publics View: War in Iraq, Democracy, Islam and Governance, Globalization. Views of a Changing World, (June 2003). Pew Global Attitudes Project. Washington: The Pew Research Center. Retrieved February 21, 2011, from http://people-press.org/reports/pdf/185.pdf

PewGlobal (2008). Global Public Opinion in the Bush Years (2001-2008). Pew Global Attitudes Project. Retrieved January 14, 2011, from http://pewglobal.org/

Pironet, P. (2007). Repères et Dates-Cles; Deux Noveux Acteurs : l'OCDE et Davos. Manière de Voir, 91, 13, 22.

Poincaré, H. (2003) (original, 1905-1910). Leçons de Mécanique Céleste, 3 tomes. Paris: Jacques Gabay.

Polanyi, K. (1957). The Economy as Instituted Process. In K. Polanyi, C.W. Arensberg, H.W. Pearson (eds.), Trade and Market in the Early Empires, New York: Free Press, 243-270.

Priest, G. \& Koji Tanaka (2009). Paraconsistent Logic. The Stanford Encyclopedia of Philosophy (Summer 2009 Edition), Edward N. Zalta (Ed.), Retrieved January 25, 2011, from http://plato.stanford.edu/archives/sum2009/entries/logicparaconsistent/

Ramonet, I. (2003). On the Record. Le Monde Diplomatique English Edition, August 2003, Retrieved January 12, 2011, from http://mondediplo.com/2003/08/01ramonet

Ramonet, I. (2004). Wars of the 21st Century: New Threats, New Fears. New York: Ocean Press

RISEPTIS (2009). Trust in the Information Society. Report of the Advisory board RISEPTIS (Research and Innovation on Security Privacy and Trustworthiness in the Information Society). European Commission's $7^{\text {th }}$ Framework, Retrieved November 28, 2009, from http://www.think-trust.eu/riseptis.html

Rivero, Á. (1998). Liberalismo Conservador (de Burke a Nozick). In J. A. Melón (ed.). Ideologías y Movimientos Políticos Contemporáneos (pp. 47-64). Madrid: Tecnos.

Rivière, P. (2010). Allende, l'Informatique et la Révolution. Le Monde Diplomatique, 57(676), 27.

Rostow, W. W. (1960). The Stages of Economic Growth. A Non-Communist Manifesto. Cambridge, Massachusetts: Cambridge University Press.

Rousseau, J.J. (2007). A Discourse Upon The Origin And The Foundation Of The Inequality Among Mankind. Minneapolis, US: Filiquarian. Also in Gutenberg Project, Retrieved January 15, 2011, from http://www.gutenberg.org/ebooks/11136

Roux, A. (2004). Les Guerres de l'Opium Revisitées. Le Monde Diplomatique, 51(607), 12.

Ruedin, E. \& Hanimann, T. (2007) Digitale Gräben oder Digitale Brücken? Chancen und Risiken für Schwellenländer (Beyond digital divides - Is there a chance for developing countries). Zurich: Benziger Bilung.

Schiller, D. (2003). End of the Telecom Revolution. Le Monde Diplomatique English Edition, August 2003. Retrieved January 13, 2011, from http://mondediplo.com/2003/08/08schiller

Schiller, D. (2009). Internet Enfante les Géants de l'Après-Crise. Le Monde Diplomatique, 56(669), 1, 18. Retrieved January 20, 2011, from http://www.monde-diplomatique.fr/2009/12/SCHILLER/18572

Schiller, H. I. (1991). No Yet the Post-Imperialist Era. Critical Studies in Mass Communication, 8, 13-28.

Smith, A. (1759 -orig.-, 1982). Theory of Moral Sentiment. In The Glasgow edition of the Works and Correspondence of Adam Smith, vol. i, Oxford: Oxford University Press.

Smith, A. (1776 -orig.-, 2009). An Inquiry into the Nature and Causes of the Wealth of Nations. Massachusetts: Digireads.com Publishing, 2009. Also available in Project Gutenberg, retrieved January 20, 2011, from http://www.gutenberg.org/files/3300

Smith, G. (2004), Behind the Screens: Examining Constructions of Deviance and Informal Practices Among CCTV Control Room Operators in the UK. Surveillance and Society, 2(2-3). Retrieved November 10, 2009, from http://www.surveillance-and-society.org/cctv.htm

Stiglitz, J. E. (2002). Globalization and Its Discontents. New York: Norton.

Story, L. (2007). It's an Ad, Ad, Ad, Ad World. The New York Times, 6 August 2007.

Street, J. (1969). An Evaluation of the Concept of Carrying Capacity. Professional Geographer, 21(2): 104-107

Tarde, G. (1986, French orig. 1904). La Opinion y la Multitud [Public Opinión and the Crowd]. Madrid: Taurus.

Tello, E. (1998). Ecopacifismo. In Mellón, J.A. (Ed.), op cit., (pp. 349-381).

TrustIS (2010). Trust in the Information Society. León, Spain, 10th-11th February, 2010. Retrieved December 15, 2010, from http://trustworthyict.inteco.es

Turner II, B.L. (1997). The Sustainability Principle in Global Agendas: Implications for Understanding Land-Use/cover Change. The Geographical Journal, 163(1997).

Vázquez Montalbán, M. (1997). Historia y Comunicación Social. Barcelona: Crítica.

Virilio, P. (1999). Télésurveillance Globale. Le Monde Diplomatique, 46(545), 4. Retrieved January 14, 2011, from: http://www.monde-diplomatique.fr/1999/08/VIRILIO/12332

Warde, I. (2007). L'Irlande Affamée par l'Economie Politique. Manière de voir, 91(January 2007), 19-21. 
Webb, M. (2007). Illusions of Security: Global Surveillance and Democracy in the Post-9/11 World. San Francisco: City Lights.

Whitrow, G. J. (2001). "Laplace, Pierre-Simon, marquis de". Encyclopaedia Britannica.

Williams, P. D. (Ed.) (2008). Security Studies: an Introduction. Oxon, Canada: Routledge.

Wolff, L. \& MacKinnon, S. (2002). What is the Digital Divide?. TechKnowLogia, July - September 2002.

Wood, D. M. \& K. Ball (Eds.) (2006) A Report on the Surveillance Society for the Information Commissioners Office by the Surveillance Studies Network. Retrieved January 20, 2011, from http://www.ico.gov.uk

Zureik, E.; Harling Stalker, L. ; Smith, E.; Lyon, D. \& Chan, Y.E. (eds.) (2010). Surveillance, Privacy, and the Globalization of Personal Information. International Comparisons. Montreal: McGill-Queen's University Press.

\section{About the Author}

José María Díaz Nafría

Obtained M.Sc. in telecommunication engineering from the Universidad del País Vasco, Bilbao, Spain, and received his $\mathrm{PhD}$ in telecommunication engineering from the Universidad Politécnica de Madrid with a dissertation on "Contributions to the electromagnetic inverse problem". He was also awarded with a M.A. in Philosophy by the Universidad Nacional de Educación a Distancia (UNED). He is currently visiting professor at the University of León, fellow professor at the Munich University of Applied Sciences, boards of directors of the Science of Information Institute, where he is also scientific advisor. $\mathrm{He}$ is also members of several international scientific societies in the field of information theories.

He was research fellow at the Vienna University of Technology and at the Technical University of Madrid. He also served as professor at the University Alfonso X el Sabio in Madrid between 1997 and 2009. He has been visiting lecturer at the University of Furtwangen, Sankt Pölten University of Applied Sciences and University of Salzburg. Co-director of the "First International Meeting of Experts in Information Theories" (León, Spain, 2008) and the "Colloquium BITae" (León, Spain, 2009) currently coordinates an interdisciplinary research group meted around the BITrum project (Elucidation of the information concept, http://en.bitrum.unileon.es). 